\title{
Imaging exhumed lower continental crust in the distal Jequitinhonha basin, Brazil
}

\author{
Loureiro Afonso ${ }^{1,{ }^{*}}$, Schnürle Philippe ${ }^{2}$, Klingelhöfer F. ${ }^{2}$, Afilhado A. ${ }^{1,3}$, Pinheiro Joao Marcelo ${ }^{2}$, \\ Evain Mikael ${ }^{2}$, Gallais Flora ${ }^{2}$, Dias N.A. ${ }^{1,3}$, Rabineau Marina ${ }^{4}$, Baltzer Agnes ${ }^{5}$, \\ Benabdellouahed Massinissa ${ }^{4}$, Soares J. ${ }^{6}$, Fuck R. ${ }^{6}$, Cupertino J.A. ${ }^{7}$, Viana A. ${ }_{9}$, Matias L. ${ }_{9}^{1}$, \\ Moulin Maryline $^{2}$, Aslanian Daniel ${ }^{2}$, Morvan Laetitia ${ }^{9}$, Mazé Jean-Pierre ${ }^{9}$, Pierre Delphine ${ }^{9}$, \\ Pitel-Roudaut Mathilde ${ }^{9}$, Rio I. ${ }^{8}$, Alves D. ${ }^{8}$, Barros Junior P. ${ }^{11}$, Biari Youssef ${ }^{8}$, Corela C. ${ }^{7}$, \\ Crozon Jacques ${ }^{8}$, Duarte J.L. ${ }^{7}$, Ducatel Cecile ${ }^{8}$, Falcão C. ${ }^{10}$, Fernagu Philippe ${ }^{8}$, \\ Vinicius Aparecido Gomes De Lima M. ${ }^{11}$, Le Piver David ${ }^{8}$, Mokeddem Zohra ${ }^{10}$, Pelleau Pascal ${ }^{9}$, \\ Rigoti C. ${ }^{11}$, Roest Walter ${ }^{9}$, Roudaut Mickael ${ }^{9}$
}

${ }^{1}$ Instituto Dom Luiz, Faculdade de Ciências, Universidade de Lisboa, Campo Grande, Ed. C1, Piso 1, 1749-016 Lisbon, Portugal

2 Institut Français de Recherche pour l'Exploitation de la MER, IFREMER, REM/GM, Centre de Brest, 29280 Plouzané, France

${ }^{3}$ Instituto Superior de Engenharia de Lisboa - ISEL, Instituto Politécnico de Lisboa, R. Conselheiro

Emídio Navarro, 1959-007 Lisbon, Portugal

${ }^{4}$ Laboratoire Géosciences Océan, UMR6538, Université de Bretagne Occidentale, Place Nicolas

Copernic, 29280 Plouzané, France

${ }^{5}$ Géolittomer, LETG UMR 6554-CNRS, Institut de Géographie et d'Aménagement Régional de

I'Université de Nantes, Campus Tertre, BP 81227, 44312 Nantes CEDEX 3, France

${ }^{6}$ Instituto de Geociências, Universidade de Brasília, Campus Darcy Ribeiro, 70910-900 Brasilia, Brazil

${ }^{7}$ Petrobras, Cenpes Research Center, Rio de Janeiro, Brazil

${ }^{8}$ Instituto Dom Luiz, Faculdade de Ciências, Universidade de Lisboa, Campo Grande, Ed. C1, Piso 1, 1749-016 Lisbon, Portugal

${ }^{9}$ Institut Français de Recherche pour I'Exploitation de la MER, IFREMER, REM/GM, Centre de Brest, 29280 Plouzané, France

${ }^{10}$ Laboratoire Géosciences Océan, UMR6538, Université de Bretagne Occidentale, Place Nicolas

Copernic, 29280 Plouzané, France

${ }^{11}$ Petrobras, Cenpes Research Center, Rio de Janeiro, Brazil

${ }^{12}$ Departamento de Geofísica, Universidade Federal do Pampa, Campus Caçapava do Sul, 96570-000

Caçapava do Sul, RS, Brazil

* Corresponding author : Afonso Loureiro, email address : maloureiro@fc.ul.pt

\begin{abstract}
:
Twelve combined wide-angle refraction and coincident multi-channel seismic profiles were acquired in the Jequitinhonha-Camamu-Almada, Jacuípe, and Sergipe-Alagoas basins, NE Brazil, during the SALSA experiment in 2014. Profiles SL11 and SL12 image the Jequitinhonha basin, perpendicularly to the coast, with 15 and 11 four-channel ocean-bottom seismometers, respectively. Profile SL10 runs parallel to the coast, crossing profiles SL11 and SL12, imaging the proximal Jequitinhonha and Almada
\end{abstract}


basins with 17 ocean-bottom seismometers. Forward modelling, combined with pre-stack depth migration to increase the horizontal resolution of the velocity models, indicates that sediment thickness varies between $3.3 \mathrm{~km}$ and $6.2 \mathrm{~km}$ in the distal basin. Crustal thickness at the western edge of the profiles is of around $20 \mathrm{~km}$, with velocity gradients indicating a continental origin. It decreases to less than $5 \mathrm{~km}$ in the distal basin, with high seismic velocities and gradients, not compatible with normal oceanic crust nor exhumed upper mantle. Typical oceanic crust is never imaged along these about $200 \mathrm{~km}$-long profiles and we propose that the transitional crust in the Jequitinhonha basin is a made of exhumed lower continental crust.

\section{Highlights}

- The transitional domain in the Jequitinhonha basin is, at least, $150 \mathrm{~km}$ wide. The transitional crust is composed of exhumed lower continental crust. Necking occurs within less than $100 \mathrm{~km}$. An anomalous velocity zone is imaged at the base of the crust.

Keywords : NE Brazil, South Atlantic Ocean, Passive margins, Wide-angle refraction seismic, PSDM, Crustal structure, Cretaceous breakup, Lower continental crust 


\section{Introduction}

43 The processes that led to the breakup of West Gondwana and the opening of the South Atlantic 44 Ocean are still not fully understood. One of the main hindrances for an accurate reconstruction of 45 West Gondwana is the lack of magnetic anomalies to establish a time-line for the oceanic crust46 spreading rate, as the breakup occurred during the Cretaceous Normal Superchron, chiefly in the 47 Central Segment of the South Atlantic Ocean (Moulin et al., 2010). The lack of magnetic anomalies 48 is counterbalanced by the presence of well-marked fracture zones and lineaments that, with the 49 knowledge of the intra-plate deformation on both Africa and South America, tightly constrain the 50 plate movements (Moulin et al., 2010; Aslanian \& Moulin, 2012).

52 The SALSA experiment is aimed at constraining the crustal structure, the segmentation and the 
geodynamical setting of the Camamu triple junction (Fig. 1), where the aborted Recôncavo Tucano - Jatobá rift system connects with the Jequitinhonha - Camamu-Almada and Jacuípe Sergipe-Alagoas rift systems. Here, the basins are set in extremely narrow margins, from less than $\sim 40 \mathrm{~km}$ to less than $100 \mathrm{~km}$ wide, and with very narrow continental shelves, which is quite rare in passive margin settings (Dominguez et al., 2013). In this paper, we present wide-angle refraction and coincident reflection data along two parallel profiles located on the Jequitinhonha basin (SL11 and SL12), extending approximately $170 \mathrm{~km}$ and $180 \mathrm{~km}$ from the continental shelf to the distal Jequitinhonha basin, and a third profile (SL10), running approximately $270 \mathrm{~km}$ parallel to the coast and crossing the Jequitinhonha and Camamu-Almada proximal basins (Fig. 1b). The conjugates of these basins are the South Gabon and Congo basins (Fig. 1c). The remaining basins studied during the SALSA project (Camamu, Jacuípe, Tucano and Sergipe-Alagoas basins) will be discussed in companion papers.

\section{Geological setting}

The Jequitinhonha - Camamu-Almada rift system extends from the Royal Charlotte bank and Cumuruxatiba basin, on the south, to the Barra and Itapuã faults, and the Recôncavo and Jacuípe basins, on the north (Fig. 1). The Jequitinhonha basin borders the south-eastern margin of the São Francisco craton, but the sampled basement is the Rio Pardo Group, low metamorphic Neoproterozoic rocks linked to the Araçuaí Orogen that make up the Rio Pardo-Nyanga aulacogen (Ledru et al., 1989; Gordon et al., 2012). This contrasts with the basement of the northern CamamuAlmada basin, which is the Archean crust of the São Francisco craton (Schobbenhaus et al., 2003), but this part of the craton is itself underlain by the Itabuna branch of the Paleoproterozoic ItabunaSalvador-Curaçá belt (Delgado et al., 2003)

During the disaggregation of Rodinia, the São Francisco and Congo cratons were never completely detached and formed a cratonic bridge (Porada, 1989, Dias et al., 2016). Neoproterozoic rifting reached the present-day Araçuaí orogen (Trompette, 1997), creating the Macaúbas-Jequitinhonha basin, a gulf-like branch of the Adamastor Ocean with an undetermined extension of oceanic crust. The main Cretaceous rift trends are strongly controlled by basement inheritance, with reactivation of previous rift structures and fold belts from the Paleoproterozoic Itabuna - Salvador - Curaçá and Neoproterozoic Araçuaí - West Congo orogens (Ferreira et al., 2013).

Rifting most likely started at the Camamu triple junction, failing at the Recôncavo - Tucano Jatobá rift system, and propagating southwards to the Camamu-Almada and Jequitinhonha basins. Rifting started in the Sergipe-Alagoas basin at a later phase (Moulin et al., 2012; Chaboureau et al., 2013). Intense fault activity occurred during the Early Aptian in the Jequitinhonha and Almada basins, south of the Taipus-Mirim Accommodation Zone (TMAZ), but also on the extreme north of the Camamu basin, forming isolated large grabens strongly bounded by basement lineaments. In the Middle Aptian, the rift architecture changed with the formation of conspicuous N-S and NE-SW hinge faults mostly concentrated in Camamu basin, north of the TMAZ. In the rest of the rift system, fault activity decreased and thermal subsidence started (Ferreira et al., 2013).

The syn-rift sedimentary sequences in the Jequitinhonha and Camamu-Almada basins are bound by two major regional discordances that, according to biostratigraphic data, indicate the rift phase lasted about $30 \mathrm{Ma}$ and ended in the Aptian/Albian transition (Küchle et al., 2005). This chronology is confirmed in the Jequitinhonha basin (Rangel et al., 2007; Chaboureau et al., 2013), but disputed in the Camamu-Almada basin, where the syn-rift sediments deposit from the Late Berriasian to the Barremian/Aptian transition (Scotchman \& Chiossi, 2009) or even to as early as the Middle Aptian (Caixeta et al., 2007; Gontijo et al., 2007). In the Early to Middle Aptian there is a major hiatus in the sedimentation with the formation of a Central Elevated Block (Chaboureau et al., 2013). 
conjugates is quite varied (Chaboureau et al., 2013). Salt is absent in the Jacuípe basin, but there are small anhydrite and halite deposits in the Camamu-Almada basin and larger deposits in the Jequitinhonha basin. Salt deposits in their conjugate basins are larger and more homogeneous, but with a different composition from the south of the Congo basin northwards. Here, they are potassium-rich evaporites with a probable hydrothermal origin that would suggest a magmatically active extensional environment (Hardie, 1990; Chaboureau et al., 2013). The same composition is also found in the Sergipe-Alagoas basin, further north on the Brazilian coast, but in almost inexpressive deposits.

\section{Data and Method}

\subsection{Seismic data}

The SALSA (Sergipe-Alagoas Seismic Acquisition) is a joint project of the Department of Marine Geosciences (IFREMER: Institut Français de Recherche pour l'Exploitation de la MER, France) and Petrobras, in collaboration with the Laboratory of "Oceanic Geosciences" (IUEM: Institut Universitaire et Européen de la Mer, France), the Faculdade de Ciências da Universidade de Lisboa (IDL, Portugal), and the Laboratório de Estudos da Litosfera, Universidade de Brasília (Brazil). The mission was conducted on the French R/V L'Atalante between April and May 2014, with the acquisition of twelve combined wide-angle refraction and high-resolution multi-channel seismics in the northeastern coast of Brazil. In this study we present the results from the three southernmost profiles, with emphasis on the two profiles that run perpendicular to the coast.

Profile SL11 was the southernmost profile of the SALSA mission (Fig. 1, Tab. 1), extending from water depths of $629 \mathrm{~m}$ to $4136 \mathrm{~m}$. Profile SL12 was parallel to SL11 (Fig. 1, Tab. 1), at a distance of approximately $40 \mathrm{~km}$, extending from water depths of $1118 \mathrm{~m}$ to $3992 \mathrm{~m}$, with the loss of instrument SL12OBS11. Both profiles cross profile SL10 (Fig. 1, Tab. 1), which runs parallel to the coast, between $50 \mathrm{~km}$ and $100 \mathrm{~km}$ from the coastline. Profile SL12 was extended onshore with 21 seismometers (Fig. 1), but no in-line shots were recorded as the batteries of the acquisition systems were already depleted at the time of shooting due to numerous marine mammal sightings that severely delayed the operations.

The OBS were deployed at 7 nautical miles intervals, and were capable of recording on four channels (1 hydrophone and a 3 component geophone). A $4.5 \mathrm{~km}$ long digital seismic streamer ensured near-offset multi-channel seismic (MCS) recording of the shots with 360 hydrophones (Figs. 2a, 2b and 2c). The seismic source was a tuned array of 16 air guns with a combined volume of $6544 \mathrm{in}^{3}$.

The reflection seismic data were pre-processed with the Geocluster (CGG-Veritas) software to include geometry corrections, wave equation multiple attenuation, shot-gather predictive deconvolution, time variant band-pass filter, and radon transform multiple attenuation. The OBS data were pre-processed to include clock drift corrections, and location corrections due to drift from the deployment position during their descent to the seafloor using the direct water wave arrival. Data quality was generally very good on all instruments and channels, with clear arrivals to offsets over $80 \mathrm{~km}$ on most instruments. Times of first and secondary arrivals where picked at their onset, without filtering whenever possible, and with band-pass Butterworth filters in all other cases.

\subsection{Forward modelling}

The wide-angle OBS data were modelled using the RAYINVR (Zelt \& Smith 1992; Zelt 1999) software package using a layer stripping-approach and iterative damped least-squares travel-time inversion at later stages. The starting parametrization for each layer was defined by screening all instruments for the most important features, either strong reflections or clear turning waves and critical refractions (Figs. 3 to 7). To avoid over-parametrization issues, only the interfaces 
discernible in the OBS data were included in the models. Arrival times of near-offset reflections were picked from the MCS data for the main sedimentary interfaces (Figs. 2a, 2b and 2c) that were also identifiable on the OBS data. These arrival times were converted to depths using the propagation velocities obtained from the OBS data. Depth and velocities of the crustal layers and 161 the upper mantle were modelled using exclusively the OBS data. Velocity gradients, relative amplitudes, and cut-off points were constrained by comparison of synthetic seismograms with the record sections (Figs. $3 \mathrm{a}$ and $3 \mathrm{~b}$, or $6 \mathrm{a}$ and $6 \mathrm{~b}$, for example). The final models (Fig. 8) show the velocity field and interface geometries of all the main sedimentary layers and basement. On SL11 (Fig. 8c), eight sedimentary layers were modelled, reaching a total thickness of $3.3 \mathrm{~km}$ at the eastern profile end and $4.1 \mathrm{~km}$ at the top of the continental slope. The propagation velocities increase gradually inside the sedimentary column (Tab. 2), although with a slight decrease towards the distal basin and only a small velocity inversion is identified, between Ps4 and Ps3. The velocities at the top of the layers are very well-constrained, with the vertical velocity gradient established from cutoff distances and relative amplitudes.

Five basement layers were modelled, based on the different refracted and reflected arrivals: upper crust, middle crust, lower crust, anomalous velocity zone, and lithospheric mantle. The upper crust seems to be present only on the continental slope, with a thickness of about $3.7 \mathrm{~km}$, but the base of the evaporites and transition to basement is not discernible in the data, which could mean that the upper part of this layer may be a mixture of evaporites and sediments. The middle crust thins from $6.5 \mathrm{~km}$ on the continental slope to $1.5 \mathrm{~km}$ on the distal basin. Thinning is almost symmetrical with respect to the top and base of the layer. The lower crust thins from $8.5 \mathrm{~km}$ on the continental slope to $2 \mathrm{~km}$ on the distal basin. The anomalous velocity zone has a relatively constant thickness, varying from $2.3 \mathrm{~km}$ to $1.5 \mathrm{~km}$ at the edges of the profile and a maximum thickness of almost $3 \mathrm{~km}$ at the necking zone. The lithospheric mantle has a propagation velocity of $8.3 \mathrm{~km} / \mathrm{s} 20 \mathrm{~km}$ below the Moho to provide a gradient capable of explaining the observations. The thickness of the "unthinned" continental crust at the western edge of the profile was set to approximately $21 \mathrm{~km}$, based on reflected arrivals at $20 \mathrm{~km}$ offset and on gravity modelling.

The model for SL11 is able to justify around $95 \%$ of the picked travel-times, and the uncertainty of each pick was estimated according to its signal-to-noise ratio (SNR), as proposed by Zelt \& Forsyth (1994). The model is very well adjusted, with a normalized $\chi^{2}$ value of 1.002 (Tab. 3).

On SL12 (Fig. 8b), eight sedimentary layers were modelled, reaching a total thickness of $4.1 \mathrm{~km}$ at the eastern extremity of the profile and $6.2 \mathrm{~km}$ at the sub-basin at the western end of the profile. The maximum sediments thickness is $9.1 \mathrm{~km}$, at $0 \mathrm{~km}$ model distance, but the model has a greater uncertainty in this region. The propagation velocities increase gradually inside the sedimentary column (Tab. 4), although with a slight decrease towards the distal basin on the shallowest layers. The deeper layers show a slight increase towards the distal basin.

The basement structure of SL12 has only four modelled layers, as no arrivals from an anomalous velocity zone similar to that of profile SL11 were identified: upper crust, middle crust, lower crust and lithospheric mantle. The upper crust has a thickness between $1.9 \mathrm{~km}$ and $2.0 \mathrm{~km}$ in the distal basin and increases to $2.9 \mathrm{~km}$ at the base of the continental slope,. The middle crust thins from 6.0 $\mathrm{km}$ in the continental slope to $1.5 \mathrm{~km}$ in the distal basin. Thinning is mostly achieved on the base of the layer, with the top of the layer almost horizontal. The lower crust is $5.5 \mathrm{~km}$ thick at the western end of the model and completely thins out at $45 \mathrm{~km}$ model distance. The lithospheric mantle has a propagation velocity of $8.3 \mathrm{~km} / \mathrm{s} 10 \mathrm{~km}$ below the Moho to provide a gradient capable of explaining the observations. The thickness of the lower crustal unit at the western edge of the profile is based on the reflected arrivals identified in instruments SL12OBS10 and SL12OBS12 and on gravity modelling. 
The model for SL12 is able to justify around 95\% of the picked travel-times, and the uncertainty of each pick was estimated according to its SNR. The model is slightly over-adjusted, with a normalized $\chi^{2}$ value of 0.794 (Tab. 5).

The model for SL10 is able to justify about $93 \%$ of the picked travel-times, and is well adjusted, with a normalized $\chi^{2}$ value of 1.742 (Tab. 7). On SL10 (Fig. 8a), five sedimentary layers were modelled, with an average total thickness of about $3 \mathrm{~km}$, and reaching a maximum total thickness of $5.4 \mathrm{~km}$ at $125 \mathrm{~km}$ model distance. Ps5, that overlays the basement, is probably a mixture of sediments and evaporites.

The basement of SL10 has four main layers: upper crust, middle crust, lower crust and lithospheric mantle. The upper basement layer has a thickness of around $2.5 \mathrm{~km}$. The middle unit has a thickness that varies from $7.3 \mathrm{~km}$ at the model edges to around $3.2 \mathrm{~km}$ at $150 \mathrm{~km}$ model distance, with thinning occurring at the top of the layer. The thickness of the lower crustal unit is approximately constant at $5.3 \mathrm{~km}$. The propagation velocity in the upper mantle increases to $8.20 \mathrm{~km} / \mathrm{s} 10 \mathrm{~km}$ below the Moho to provide a gradient capable of explaining the observations. Although the anomalous velocity zone imaged on SL11 reaches the crossing with SL10, the poor ray coverage of the upper mantle means that there are not enough observations to justify the inclusion of this feature on SL10, keeping in line with the minimum structure approach, i.e., the final velocity model should only contain the structure required by the data (Zelt \& Smith, 1992).

\subsection{PSDM}

To verify the accuracy of the final velocity model, the MCS data of each profile were pre-stack depth migrated (PSDM), and a residual move-out analysis was performed, using the Seismic Unix package (Stockwell 1999; Cohen and Stockwell, 2015). A script is available in the supplementary material. The final velocity layered model was converted to a $50 \times 25 \mathrm{~m}$ spaced grid, and used to compute travel-time tables regularly spaced at $150 \mathrm{~m}$ (the same spacing as the recorded shots) along the profile by paraxial ray tracing. Solving the eikonal equation compensates travel-times in shadow zones. The travel-time tables are used to calculate a common offset Kirchhoff depth migration. Migrated traces are output as common image gathers (CIG) binned at $25 \mathrm{~m}$, with 30 offset-classes between 249 and $4596 \mathrm{~m}$, spaced at $150 \mathrm{~m}$. SALSA11 (Fig. 9a), SALSA12 (Fig. 9e), and SALSA10 (Fig. 9c) were migrated up to a depth of $18 \mathrm{~km}$, showing very good resolution in the sedimentary layers, and a good resolution in the crust, with good agreement between strong reflectors and their wide-angle estimated depths.

Calculating the residual move-out (RMO) allows a dip-independent velocity analysis on the migrated CIG. This implies that, if the velocity model is close to the true medium velocity, all common offset migrated panels map the recorded seismic events to the same reflector depth. If the velocity model significantly deviates from the true medium velocity, the move-out from near to far offset translates into an interval velocity correction (Liu and Bleistein, 1995). Additionally, depth migrated gathers are excellent records of amplitude variations with offset, and therefore are indicators of in-situ rheological changes. The residual move-out behaviour coupled with the seismic character from PSDM images are key elements to locate accurately major geological contacts, moreover with higher horizontal resolution when compared to the OBS records.

The RMO analysis of the migrated SALSA11 (Fig. 9b), SALSA12 (Fig. 9f), and SALSA10 (Fig. 9d) sections shows mostly sub-horizontal arrivals, indicating a good agreement between the modelled and true medium velocities in the entire sedimentary basin and upper crust. Coherence is lost immediately below the basement, due to the arrival of the free surface multiples.

\subsection{Gravity modelling}

During the cruise, filtered gravity data were acquired every $10 \mathrm{~s}$ using a Lockheed Martin BGM-5 
dynamic gravimeter installed as close as possible to the centre of gravity of the vessel. This gravimeter additionally calculates the Eötvös correction, and the Free Air and Bouguer gravity anomalies. The data were merged with the navigation data and corrected for instrumental drift using the Caraïbes software, developed by Ifremer. Gravimeter drift was corrected using three measurements at absolute gravity points in Maceió, São Paulo and Salvador. Outliers were manually cleaned. The precision of the measurements is evaluated at $1 \mathrm{mGal}$.

The observed gravity in the Jequitinhonha basin is relatively smooth, with a positive anomaly on the edge of the continental shelf, and a negative anomaly that starts at the location of profile SL10 towards the distal part of the basin (Fig. 1a). On the global satellite-derived gravity (Sandwell \& Smith, 2009; Sandwell et al., 2013, 2014), this negative anomaly is connected to a negative anomaly concentric with the pronounced gravimetric high at the Royal Charlotte bank (Fig. 1a).

An estimate of crustal density can be obtained by correlating the acoustic wave propagation velocities with rock densities (Christensen \& Mooney, 1995). Although there is no absolute relationship between acoustic propagation velocity and density, gravity modelling shows that the seismic model is compatible with the measured gravity anomaly.. Areas of the model unconstrained or poorly constrained by seismic data can be further constrained as a first order interpolation by gravity modelling.

For profile SL11, we built a 2-D model consisting of 171 homogeneous density blocks, by conversion of seismic velocity to density according to Ludwig et al. (1970). The density conversion of our velocity model (Tab. 8) is able to predict the main trend of the gravity anomaly (Fig. 8c). The regional trend was removed by varying the densities in the deep lithospheric mantle in the range between $3330 \mathrm{~kg} / \mathrm{m}^{3}$ and $3345 \mathrm{~kg} / \mathrm{m}^{3}$.

The densities for the upper mantle must be consistent with the geological setting, but in this complex region, with Archean and Proterozoic units and at the northern limit of the Neoproterozoic rifting, several hypotheses are possible. The modelled mantle densities are consistent with: a moderately depleted Archean Sub-continental lithospheric mantle (SCLM), that can have mean densities as low as $3310 \mathrm{~kg} / \mathrm{m}^{3}$; a depleted Proterozoic mantle, with mean densities as low as 3330 $\mathrm{kg} / \mathrm{m}^{3}$; (Poudjom Djomani et al., 2001); or with a very reworked and possibly enriched Paleoproterozoic serpentinized forearc mantle (Chaves et al., 2016). Present-day lightly serpentinized forearc mantles have mean densities starting at $3200 \mathrm{~kg} / \mathrm{m}^{3}$ (Hyndmand \& Peacock, 2003).

The largest difference between observed and calculated gravity anomaly, $13.0 \mathrm{mGal}$ (Fig. 8c), occurs close to the continental slope where thinning is more pronounced and seismic coverage is poorer. The calculated gravity anomaly is also consistent with the satellite-derived gravity values observed on parallel profiles extracted north and south of the profile .

For profile SL12, we built a 2-D model consisting of 106 homogeneous density blocks. The density conversion of our velocity model (Tab. 8) is able to predict the main trend of the gravity anomaly (Fig. 8b). The density of the mantle is consistent with the geological setting.

The largest difference between observed and calculated gravity anomaly occurs close to the western edge of the model where the maximum difference reaches $9.6 \mathrm{mGal}$ (Fig. 8b). The calculated gravity anomaly is well within the values observed on parallel profiles extracted north and south of the profile, derived from satellite gravity measurements.

Gravity modelling for profile SL12 is also consistent with the existence of the lower crustal unit in the proximal basin. Without it, the calculated gravity anomaly does not match the data. 
For profile SL10, we built a 2-D model consisting of 92 homogeneous density blocks, but precise gravity modelling is hindered by the presence of salt, sometimes mixed with sediments, chiefly in the Camamu-Almada basin, with differences between modelled and observed values up to $50 \mathrm{mGal}$. In the region between profiles SL11 and SL12, the largest difference is under 20 mGal (Fig. 8a). .. On the southern end of the profile, ray coverage is very poor in the upper mantle, and we cannot exclude the contribution of the anomalous velocity zone imaged on SL11. To avoid boundary effects the velocity model is extended north and south before calculating the gravity anomaly, but without taking into account the change of topography, bathymetry and crustal thickness. The mass deficit that is apparent in the gravity anomaly of SL10 is due to the regional influence of the thick continental crust of the São Francisco craton in the north and the Royal Charlotte bank in the south. Load anomaly in all profiles is within acceptable ranges for a crust in isostatic equilibrium (Whitmarsh et al. 1996).

\subsection{Crossings with SL10}

To avoid operator and interpretation bias, profile SL10 was modelled independently of profiles SL11 and SL12, by another operator, using different tools for data picking and filtering. SL10 runs parallel to the coast and images the crust perpendicularly to the major structural features. Some differences are expected, chiefly for the deepest interfaces and foremost on those constrained by wide-angle reflections. However, when comparing the $1 \mathrm{D}$ velocity-depth profiles extracted at the crossing points, the most noticeable discrepancy is the total crustal thickness of SL11 and SL10 (Figs. 10b and 10c). SL11 has a $8 \mathrm{~km}$ thick crust, while the crust on SL10 reaches a thickness of 9 $\mathrm{km}$. This is explained by the inclusion of the anomalous velocity layer seen in SL11 in the lower crust of profile SL10. The direction of shooting of SL10 and the presence of salt makes it very difficult to model this feature.

\section{Model evaluation}

\subsection{Indirect model evaluation}

Models are evaluated not only by the number of justified observations and global data fit, but also by the uniformity and density of their ray coverage, smearing, resolution and the number of rays that constrain each node (hitcounts).

All three models are globally well covered with rays, and well-constrained from arrival times. Localized defocusing effects caused by the salt layer are apparent in the lower crustal layers of profile SL11. The resolution is generally very good (Fig. 11). Some sedimentary layers show lower resolution, but they were constrained using the near-offset reflection data.

All layers show hit-counts larger than 2000, on profiles SL10 and SL11, and larger than 1000, on profile SL12, indicating that the velocities are well constrained. Hit-counts for interface depths are larger than 1000, on profiles SL11 and SL12, and larger than 2000, on profile SL10, indicating a good constraint also on interface depths and topographies. Smearing is low on all three models, suggesting that they are not over-parameterized.

\subsection{Uncertainty estimation using VMONTECARLO}

VMONTECARLO (Loureiro et al., 2016) was applied on the crustal layers of the final models of SL10, SL11 and SL12, using the Metropolis algorithm and adaptive variance to increase the convergence. The first quality threshold used to establish the model ensemble (ME) was set to twice the preferred model's quality of fit (in terms of RMS, number of traced rays and $\chi^{2}$ ). Two million random models were generated for each profile.

For SL11, 16,289 models were at least as good as the preferred model, in terms of number of 
justified observations and data fit, and used to build a global uncertainty map. . The global uncertainty map for profile SL11 (Figs. 12c and 12d) shows that the model is generally well constrained, apart from very localized defocusing effects caused by the salt layers. Only the deeper crustal layers admit a broader range of velocity values while still satisfying the global data fit, but the ray coverage in these regions is poor. Interface depths are also well determined.

A direct result of the VMONTECARLO uncertainty estimation is the output of a model that fits the dataset better than the preferred model. In this case, the best model is capable of tracing 8097 rays (justifying $97.0 \%$ of the data), with an RMS of $0.069 \mathrm{~s}$ and a $\chi^{2}$ of 1.930 . The original model had justified 7910 observations, had a $\chi^{2}$ of 3.193 and an RMS of $0.089 \mathrm{~s}$. Even if the best model has a better data fit and justifies more observations than our preferred model, the best model (dashed lines in Figs. 12a and 12b) does not deviate significantly from the preferred solution (solid lines in Figs. $12 \mathrm{a}$ and $12 \mathrm{~b}$ ). This means that the preferred model is already a good solution.

For SL12, we used VMONTECARLO with the same options as for SL11. The first quality threshold used to establish the ME was set to twice the preferred model's quality of fit (in terms of RMS, number of traced rays and $\chi^{2}$ ). SL12 has less data points (6490 observations) than SL11 (8348 observations), but with a better quality of fit, measured in both terms of RMS and $\chi^{2}$. Given the current data interpretation, the model solution also seems to be more unique, as some arrivals are constrained to very specific features.

For SL12, only 6 models were at least as good as the preferred model, in terms of number of justified observations, RMS and $\chi^{2}$ value, indicating that the preferred model is a very good solution. If parameters are relaxed to match the quality of fit of model SL11 (the same RMS and $\chi^{2}$ values) but requiring at least the same number of traced rays as the preferred model, this number increases to 26,043 models ( $1.3 \%$ of the ME). However, this subset of the ME does not include the best random model.

To generate an uncertainty map comparable to that of SL11 (Figs. 12c and 12d), the ME of SL12 was filtered to show only models with a $\chi^{2}$ of 3.193 and an RMS of $0.089 \mathrm{~s}$ (the same values used for SL11). The ME was further filtered to show only models capable of tracing at least 5,500 rays to use a similar number of models on both profiles. The final ME had 15,324 models.

The global uncertainty map for profile SL12 (Figs. 12e and 12f) shows that the central part of a model is generally well constrained. The lower crustal units in the necking zone, sparsely-covered by rays, admit very different values while keeping the global fit at acceptable levels. Interface depths are well constrained.

The best model found was capable of tracing 5852 rays (justifying $90.2 \%$ of observations), with an RMS of $0.067 \mathrm{~s}$ and a $\chi^{2}$ of 1.808 . The original model traced 5886 rays, had a $\chi^{2}$ of 2.035 and an RMS of $0.071 \mathrm{~s}$. It too, did not deviate significantly from the preferred model (dashed and solid lines in Figs. 12c and 12d), indicating that the preferred model is already a very good solution.

For SL10, 2,528 models were capable of fitting the data with a $\chi^{2}$ value better than 3.193 (the same value used for SL11), an RMS up to $0.179 \mathrm{~s}$, and capable of tracing at least $85 \%$ of the preferred model's traced rays. The global uncertainty map for profile SL10 (Figs. 12a and 12b) shows that the crustal layers are generally well constrained, with some noticeable defocusing effects caused by the presence of salt. The velocities of the upper mantle have higher uncertainties. The best random model does not deviate significantly from the preferred solution and is capable of tracing 11,961 rays, with an RMS of $0.129 \mathrm{~s}$ and a $\chi^{2}$ of 1.673. It has a better fit than the preferred model for SL10, but it justifies less observations. 
1D slices of these global uncertainty maps, coloured according to model score, were used to study the profile crossings. We find that each of the preferred models is compatible with the uncertainty 418 bounds of the profile it crosses (Fig. 10), and generally close to the random models with higher 419 scores.

\subsection{Comparison with GXT}

SALSA11 was shot along the track of a still not published seismic acquisition line, profile ION GXT-1900. This dataset provides additional constraints to the sedimentary basin and crustal structure. On the line drawing of this profile there are several deep crustal reflectors and what appears to be a highly reflective, undulating Moho. Due to the spacing of the instruments, refraction data are typically unable to retrieve small reflector wavelengths, but the final velocity model of SL11 is capable of bounding the major units identified in the ION GXT-1900 profile with a very good agreement (Fig. 13).

\section{Discussion}

Profiles SL11 and SL12 were aimed at imaging the necking zone and the deep Jequitinhonha basin. Profile SL10, running parallel to the coast, was aimed at imaging the necking zone and proximal Jequitinhonha and Camamu-Almada basins.

The interpretation of the SL11 and SL12 wide-angle models allowed us to identify two main regions (Figs. 15 and 16). The first region is the necking zone, between $0 \mathrm{~km}$ and $\sim 50 \mathrm{~km}$ model distance, where the continental crust thins from $19-23 \mathrm{~km}$ to about $13 \mathrm{~km}$. The second region, from $50 \mathrm{~km}$ model distance to the end of profiles SL11 and SL12, is the deep basin.

The southernmost region of profile SL10 shows a crustal structure of a thinned continental crust nature (Fig. 17) that is consistent with what is observed on profiles SL11 and SL12, at the crossing with this profile. North of the crossing with SL12, already in the Camamu-Almada basin, it neither shares features with typical continental crust nor typical oceanic crust, but those of a transitional domain that is discussed next.

In profile SL12, a third crustal unit is present, modelled with lower propagation velocities than the anomalous velocity zone of profile SL11. This layer is constrained by reflections at both the top and base (Figs. 6 and 7), and is also required to improve the fit in the gravity anomaly model.

The unthinned continental crust is not imaged by any of the presented profiles, however, the width of the first region, the necking zone, can be estimated less than $100 \mathrm{~km}$, taking into account a total crustal thickness of between $37 \mathrm{~km}$ and $41 \mathrm{~km}$ (Assumpção et al., 2013) taken at approximately 50 $\mathrm{km}$ inland.

The second region, the deep basin, has a crust that cannot be classified as having an oceanic nature, as the propagation velocities, gradients and layer thicknesses are inconsistent with typical Atlantic oceanic crust of comparable age (Figs. 15 and 16). Two crustal layers are present, with an upper layer that reaches a maximum thickness of $3 \mathrm{~km}$ and has high seismic propagation velocity (above $5,5 \mathrm{~km} / \mathrm{s}$ ) and a strong gradient. The Moho is also marked by a sharp increase in velocity and clear PmP reflections. Two hypotheses can be made for the nature of the crust in this region: exhumed mantle exhumed lower continental crust.

\subsection{Exhumed mantle}

Continental mantle exhumation and subsequent serpentinization has been proposed as an explanation for the formation of the ocean-continent transitional crust at the later phases of the rifting process in the Atlantic Ocean, mainly based on the very specific Galician margin studies (Boillot et al., 1987; Brun \& Beslier, 1996; Manatschal, 2001; Lavier \& Manatschal, 2006). 
To test the hypothesis of mantle exhumation, the 1D velocity-depth profiles extracted along the profiles were compared to similar profiles extracted from wide-angle seismic models (Figs. 18a, Galician margin, where the ocean-continent transition zones have been interpreted as exhumed mantle, serpentinized upper mantle, or a mixture of both. In the southern Galician margin serpentinized upper mantle and lower continental crust materials were drilled during Legs 173 and 149 of the Ocean Drilling Program (Chian et al., 1999), with the lower continental crust materials being interpreted as rafts that float in an overall upper mantle exhumation regime that occurs along a deep detachment (Boillot et al., 1987; Manatschal, 2001). The 1D velocity-depth profiles are also compared a compilation of mean velocity-depth variations in the ocean-continent transition (Fig. 18d - Minshull, 2009) of profiles in the previously compared regions and the UK western approaches margin, where an anomalously high $\mathrm{Vp} / \mathrm{Vs}$ ratio indicates the presence of strongly serpentinized rocks (Bullock \& Minshull, 2005).

In the southern Iberian Abyssal Plain (IAM-9 profile, Fig. 18a), a zone inferred to be exhumed upper mantle has a thickness of $5 \mathrm{~km}$ divided into two layers (Dean et al., 2000). An upper, high velocity-gradient layer, $2 \mathrm{~km}$ to $4 \mathrm{~km}$ thick, interpreted to be upper mantle serpentinized peridotite (with a mean bulk serpentinization from $25 \%$ to $100 \%$ ) along faults, which may have been subsequently locally intruded by the products of decompression melting in the mantle, and a lower layer up to $4 \mathrm{~km}$ thick with a $\mathrm{P}$ wave propagation velocity between $7.3 \mathrm{~km} / \mathrm{s}$ and $7.9 \mathrm{~km} / \mathrm{s}$, representing mantle peridotite with a mean bulk serpentinization of $<25 \%$, possibly concentrated along fewer, but steep cutting faults. On the IAM-9 profile, reflections from the Moho, representing the serpentinization front, are weak in the wide-angle seismic data and absent in the normal incident data.

On the eastern Grand Banks of Newfoundland, profile SCREECH-2 (Fig. 18b) shows a $\sim 25 \mathrm{~km}$ wide zone with a smooth basement, characterized by velocities higher than $6.3 \mathrm{~km} / \mathrm{s}$, increasing to $7.7 \mathrm{~km} / \mathrm{s}$ at a depth of $5 \mathrm{~km}$. This region is interpreted, from analogies with the Iberian Margin, as being exhumed upper mantle material (van Avendonk et al., 2006). Similar zones are much wider $(60-160 \mathrm{~km})$ on SCREECH-3 (Lau et al., 2006) and also on the Iberia Abyssal Plain (Dean et al., 2000).

However, in the southern Galician margin, where upper mantle materials were drilled, the crustal structure was imaged by the CAM wide-angle profile (Minshull et al., 1998; Chian et al., 1999), showing a continuous increase of velocity with depth and absence of intra-basement interfaces (Fig. $18 \mathrm{c})$.

The velocity structure of the Jequitinhonha basin is noticeably different from that of these profiles, where the basement is presumably formed of exhumed mantle. When compared to the other three areas, the Jequitinhonha basin has an upper layer with much higher velocities and lower gradients, and there are clear reflections from the Moho seen in both wide-angle and near offset seismic sections that are associated with strong velocity contrasts. These reflections at the base of the lower layer are absent in the other three profiles. These differences clearly demonstrate that the basement of the Jequitinhonha basin cannot be formed of exhumed mantle.

\subsection{Exhumed lower continental crust}

Between thinned continental crust and pure oceanic crust, the presence of exhumed lower continental crust has been proposed for other segments of the South Atlantic Ocean (Moulin et al.; 2005; Aslanian et al., 2009; Klingelhöfer et al., 2015; Evain et al., 2015; Moulin et al., 2016) and the Mediterranean Sea (Afilhado et al., 2015; Moulin et al., 2015). 
To test the exhumed lower continental crust hypothesis, we compared the 1D velocity-depth profiles from the Jequitinhonha basin with those extracted from wide-angle seismic models in the Santos basin (SANBA experiment) and Gulf of Lion and Provençal basin (Sardinia experiment), where the ocean-continent transition zones have been interpreted to be exhumed lower crust. Bott (1971), Aslanian et al. (2009) have proposed that this lower continental crust may feed the first oceanic accretion process

The 1D velocity-depth profiles extracted along SL11 and SL12 are comparable to those from regions where exhumed lower continental crust is proposed, such as the Provençal basin (Fig. 18e), where the gradients and thicknesses are similar; and the Santos basin (Fig. 18f), where the propagation velocity gradients are also very similar, but the crust is thicker. There are also only two crustal layers and a marked velocity step at the top of the mantle (Figs. 18e and 18f) in both regions. These observations lead us to infer that this domain is most likely comprised of exhumed lower continental crust.

The Almada section of profile SL10 shows similarities with the proximal part of the exhumed lower continental crust domain of profiles SL11 and SL12, most notably in terms of upper crust thickness and velocity gradient in the lower crust. The closeness to the necking zone may explain most of the differences found between profile SL10 and the profiles that run perpendicularly to the coast. Layer thicknesses and propagation velocities at the top of the crust are comparable to those of the thinner parts of the exhumed continental crust domain of the Santos basin (Fig. 18f), as well as the propagation velocities at the top of the basement.

\subsection{Boudin-like feature}

A specific feature of the southern-most profile (SL11) is an anomalous velocity zone that underlays the lower crust. The P-wave propagation velocities in this relatively thin layer are over $7.6 \mathrm{~km} / \mathrm{s}$, making the reflection at the top of this layer a candidate seismic Moho (Prodehl et al., 2013), but it is much more reflective than the mantle, indicating a crustal nature (Cook et al., 2010; Hammer \& Clowes, 1997). The internal reflectivity is apparent in the GXT-1900 line drawing (Fig. 13), but also in the PSDM (Fig. 2b) and MCS sections (Fig. 9a).

The anomalous velocity zone bounds an high-amplitude undulated reflector identified in cyan in the line-drawing of profile ION GXT-1900 (Fig. 13). This reflector shares similarities with the "Mreflector", proposed by Blaich et al. (2010) for the Camamu-Almada basin. The wavy character of deep reflectors is also found in the conjugate margin, for example in profile PROBE23 (Rosendahl et al., 1991). In the Middle South Gabon Basin, a similar undulating reflector is also identified, the "G-reflector" (Dupré et al., 2011). The "G-reflector" appears also at approximately $10 \mathrm{~s}$ twt, and is interpreted as the transition between an upper crust and the result of mafic underplating of the continental crust that has been thinned during extension. A similar anomalous velocity zone, with Pwave seismic propagation velocity exceeding $7.7 \mathrm{~km} / \mathrm{s}$, is also present in the Upper South Gabon basin, on profile SPOG2 (Wannesson et al. 1991).

The same feature is not modelled on profile SL12, but as the maximum reciprocal offsets are smaller in this profile, due to the smaller number of deployed instruments, it may not be possible to accurately image this feature if it exists. Additionally, profile SL12 is located on the transition between the Jequitinhonha and Almada basins, near the Olivença basement high, which could mark a different basement fabric. However, taking into account the estimated uncertainties for this model (Figs. 12a and 12b), an anomalous velocity zone similar to the one modelled on profile SL11 cannot be excluded.

A possible interpretation for the anomalous velocity layer is that the lower continental crust, as it is thinned and/or exhumed, begins to flow (Bott, 1971; Buck et al., 1999; Aslanian et al., 2009) and 
form lithospheric-sized boudins (Fig. 14). A similar mechanism has also been proposed for the Uruguayan margin (Clerc et al., 2015). In this process, part of this crust is enriched with mafic and ultramafic mantle materials, which explain the increase of the seismic propagation velocity. Such intrusions of mantle-derived melts into the lower crust have been proposed in the Paleoproterozoic block of the Ukrainian Shield, where a layer with seismic propagation velocity of $7.6 \mathrm{~km} / \mathrm{s}$ is observed above the Moho (Thybo et al., 2003; Thybo \& Artemieva, 2013). As the anomalous velocity zone is not apparent on profile SL12, other possibilities are that this feature is linked to the Miocene Abrolhos volcanism (intruded upper mantle), connected to upper mantle foliation due to plate movement along the Bode Verde Fracture Zone, or even indicative of boudinage of the deepest parts of the continental crust induced by a transfer zone that is expressed by the Royal Charlotte Bank.

\section{Conclusions}

The Jequitinhonha basin is set on a narrow margin, with the complete necking of the continental crust occurring within less than $100 \mathrm{~km}$.

The typical oceanic crust was not reached in profiles SL11 and SL12. Taking this into account and the limit of the necking zone, the transitional domain in the Jequitinhonha basin is, at least, $150 \mathrm{~km}$ wide, which is in agreement with the transitional domain proposed for the same area by Blaich et al. (2008). Seismic velocity gradients seem to rule out a purely continental origin and Moho reflections discard a serpentinized upper mantle provenance. The transitional domain is instead most probably composed of exhumed continental lower crust. This is in accordance with the hypothesis of Aslanian et al. (2009), who proposed a transitional crust in this region.

On profile SL11 there is an anomalous velocity zone that underlays the lower crust and bounds high-amplitude undulating reflectors. The seismic propagation velocities and the geometry of the reflectors suggest the existence of a boudin-like feature probably linked to the crustal thinning, with oceanward creep of the lower crust.

In the Jequitinhonha basin, the upper continental crust completely thins out at the limit of the salt province (Fig. 19). The middle and lower crusts are exhumed in the distal basin, with shearing and oceanward creep of the deepest parts of the lower crust. Ultramafic intrusions in the lower crust are also possible.

\section{Acknowledgements}

We thank two anonymous reviewers for their excellent suggestions, and their constructive and exhaustive reviews that significantly improved this manuscript. We are indebted to the captain, crew, and MCS technical team of the R/V L'Atalante. We also thank J. Crozon, P. Fernagu, P. Pelleau and M. Roudaut, the OBS technical team, and J. Soares, R. Fuck, M. Lima, J. Pinheiro, F. Lima, M. Sobrinho, P. Resende, R. Oliveira, N. Dias, C. Corela, J. Duarte, D. Alves and L. Matias, the land stations deployment team. The GMT (Wessel \& Smith 1998), Seismic Unix (Stockwell 1999; Cohen and Stockwell, 2015), and Geocluster (CGG-Veritas) software packages were used extensively in the preparation of this paper. Processing of the high resolution seismic data was done by A. Baltzer, M. Benabdellouahed, and M. Rabineau. The geodynamic interpretations were done by D. Aslanian and M. Moulin. R. Fuck acknowledges CNPq, Brazil research fellowship and INCT Estudos Tectônicos research grant.

The dataset collected during the SALSA experiment is protected under a partnership with Petrobras. Any request has to be addressed to Daniel Aslanian (aslanian@ifremer.fr) and Adriano Viana (aviana@petrobras.com.br).

\section{Contributions}


The SALSA Project was led by D. Aslanian and M. Moulin, from Ifremer, and A. Viana, from Petrobras. Processing of the high resolution seismic data was done by A. Baltzer, M. Benabdellouahed, and M. Rabineau. The geodynamic interpretations were done by D. Aslanian and M. Moulin. Modelling of profiles SL11 and SL12 was done by A. Loureiro. Modelling of profile SL10 was done by F. Klingelhöfer. Profile SL09 was modelled by A. Afilhado. F. Gallais modelled profiles SL07 and SL08. M. Evain modelled profiles SL05 and SL06. Profiles SL01 and SL02 were modelled by J. M. Pinheiro. Modelling of profiles SL03 and SL04 and processing of the deepsounding reflection seismic data was done by P. Schnürle.

The Salsa Team is composed by: Morvan, L. ${ }^{2}$, Mazé, J.P. ${ }^{2}$, Pierre, D. ${ }^{2}$, Roudaut-Pitel ${ }^{2}$, M., Rio, I. ${ }^{1}$, Alves, D. ${ }^{1}, \square$ Barros Junior, P. ${ }^{7}, \square$ Biari, Y. ${ }^{2}$, Corela, C. ${ }^{1}$, Crozon ${ }^{2}$, J., Duarte, J.L. ${ }^{1}, \square$ Ducatel, C., ${ }^{2} \square$ Falcão, C. ${ }^{7}$, Fernagu, P. ${ }^{2}$, Vinicius Aparecido Gomes de Lima, M. ${ }^{8}$, Le Piver, D. ${ }^{2}$, Mokeddem, Z. ${ }^{4}$, Pelleau, P. ${ }^{2}$, Rigoti, C. ${ }^{7}$, Roest, W. ${ }^{2}$ \& Roudaut, M. ${ }^{2}$.

\section{References}

Afilhado, A., M. Moulin, D. Aslanian, P. Schnürle, F. Klingelhöfer, H. Nouzé, M. Rabineau, E. Leroux, \& M.-O. Beslier (2015). "Deep crustal structure across a young passive margin from wideangle and reflection seismic data (The SARDINIA Experiment) - II. Sardinia's margin". Bulletin de la Société Géologique de France 186.4-5, 331-351. issn: 0037-9409. doi: 10.2113/gssgfbull.186.45.331

Aslanian, D., M. Moulin, J.-L. Olivet, P. Unternehr, L. Matias, F. Bache, M. Rabineau, H. Nouzé, F. Klingelhöfer, I. Contrucci, \& C. Labails (2009). "Brazilian and African passive margins of the Central Segment of the South Atlantic Ocean: Kinematic constraints". Tectonophysics 468.1, 98112. doi: 10.1016/J.TECTO.2008.12.016

Aslanian, D. \& M. Moulin (2012). "Palaeogeographic consequences of conservational models in the South Atlantic Ocean". Geological Society, London, Special Publications 369.1, 75-90. doi: $10.1144 / \mathrm{SP} 369.5$

Assumpção, M., M. Bianchi, J. Julià, F. L. Dias, G. S. França, R. Nascimento, S. Drouet, C. G. Pavão, D. F. Albuquerque, \& A. E. Lopes (2013). "Crustal thickness map of Brazil: data compilation and main features". Journal of South American Earth Sciences 43, 74-85. doi: 10.1016/j.jsames.2012.12.009

van Avendonk, H. J. A., W. S. Holbrook, G. T. Nunes, D. J. Shillington, B. E. Tucholke, K. E. Louden, H. C. Larsen, \& J. R. Hopper (2006). "Seismic velocity structure of the rifted margin of the eastern Grand Banks of Newfoundland, Canada". Journal of Geophysical Research: Solid Earth 111.B11. doi: 10.1029/2005JB004156

Bizzi, L. A., C. Schobbenhaus, R. M. Vidotti, \& J. H. Gonçalves, eds. (2003). "Geologia, tectônica e recursos minerais do Brasil: texto, mapas \& SIG". CPRM - Serviço Geológico do Brasil. isbn: 85-230-0790-3

Blaich, O. A, Tsikalas, F. \& J. I. Faleide (2008). "Northeastern Brazilian margin: Regional tectonic evolution based on integrated analysis of seismic reflection and potential field data and modelling". Tectonophysics 458.1, 51-67. doi: 10.1016/J.TECTO.2008.02.011

Blaich, O. A., J. I. Faleide, F. Tsikalas, R. Lilletveit, D. Chiossi, P. Brockbank, \& P. Cobbold (2010). "Structural architecture and nature of the continent-ocean transitional domain at the Camamu and Almada Basins (NE Brazil) within a conjugate margin setting". Geological Society, London, Petroleum Geology Conference series. Vol. 7. Geological society of London, 867-883. doi: $10.1144 / 0070867$ 
676

677

678

679

680

681

682

683

684

685

686

687

688

689

690

691

692

693

694

695

696

697

698

699

700

701

702

703

704

705

706

707

708

709

710

711

712

713

714

715

716

717

718

719

720

721

722

723

724

725

726

727
Boillot, G., M. Recq, E. L. Winterer, A. W. Meyer, J. Applegate, M. Baltuck, J. A. Bergen, M. C. Comas, T. A. Davies, K. Dunham, C. A. Evans, J. Girardeau, G. Goldberg, J. haggerty, L. F. Jansa, J. A. Johnson, J. Kasahara, J. P. Loreau, E. Luna-Sierra, M. Moullade, J. Ogg, M. Sarti, J. Thurow \& M. Williamson (1987). "Tectonic denudation of the upper mantle along passive margins: a model based on drilling results (ODP leg 103, western Galicia margin, Spain)". Tectonophysics 132.4, 335-342. issn: 0040-1951. doi: 10.1016/0040-1951(87)90352-0

Bott, M. H. P. (1971). "Evolution of young continental margins and formation of shelf basins". Tectonophysics 11, 319-327. doi: 10.1016/0040-1951(71)90024-2

Brun, J. \& M. Beslier (1996). "Mantle exhumation at passive margins". Earth and Planetary Science Letters 142.1-2, 61-173. issn: 0012-821X. doi: 10. 1016/0012-821x(96)00080-5

Buck, W. R., Lavier, L. L. \& A. N. Poliakov (1999). "How to make a rift wide". Philosophical Transactions-Royal Society of London Series a Mathematical Physical and Engineering Sciences 357, 671-693. doi: 10.1098/rsta.1999.0348

Bullock, A. D. \& T.A Minshull (2005). "From continental extension to seafloor spreading: crustal structure of the Goban Spur rifted margin, southwest of the UK". Geophysical Journal International 163, 527-546. doi: 10.1111/j.1365-246x.2005.02726.x

Caixeta, J. M., P. d. S. Milhomen, R. E. Witzke, I. S. S. Dupuy, \& G. A. Gontijo (2007). "Bacias de Camamu". Boletim de Geociências da Petrobras 15.1, 455-461

Chaboureau, A.-C., F. Guillocheau, C. Robin, S. Rohais, M. Moulin, \& D. Aslanian (2013). "Paleogeographic evolution of the central segment of the South Atlantic during Early Cretaceous times: Paleotopographic and geodynamic implications". Tectonophysics 604, 191-223. doi: 10. 1016/j.tecto.2012.08.025

Chaves, C., Ussami, N. \& J. Ritsema (2016). "Density and P-wave velocity structure beneath the Paraná Magmatic Province: Refertilization of an ancient lithospheric mantle". Geochemistry, Geophysics, Geosystems 17.8, 3054-3074. doi: 10.1002/2016gc006369

Chian, D., K. E. Louden, T. A. Minshull, \& R. B. Whitmarsh (1999). "Deep structure of the oceancontinent transition in the southern Iberia Abyssal Plain from seismic refraction profiles: Ocean Drilling Program (Legs 149 and 173) transect". Journal of Geophysical Research: Solid Earth 104.B4, 7443-7462. doi: 10.1029/ 1999jb900004

Christensen, N. \& W. Mooney (1995). "Seismic velocity structure and composition of the continental crust: A global view". Journal of Geophysical Research Atmospheres 100.B7, 97619788. doi: 10.1029/95JB00259

Clerc, C., Jolivet, L. \& J.-C. Ringenbach (2015). "Ductile extensional shear zones in the lower crust of a passive margin". Earth and Planetary Science Letters 431, 1-7. doi: 10.1016/j.eps1.2015.08.038

Cohen, J. K. and J. W. Stockwell Jr. (2015). CWP/SU: Seismic Un*x Release No. 44R1: an open source software package for seismic research and processing, Center for Wave Phenomena, Colorado School of Mines

Cook, F. A., D. J. White, A. G. Jones, D. W. S. Eaton, J. Hall, \& R. M. Clowes (2010). "How the crust meets the mantle: Lithoprobe perspectives on the Mohorovičić discontinuity and crust-mantle 
transition”. Canadian Journal of Earth Sciences 47.4, 315-351. doi: 10.1139/E09- 076

Dean, S. M., T. A. Minshull, R. B. Whitmarsh, \& K. E. Louden (2000). "Deep structure of the ocean-continent transition in the southern Iberia Abyssal Plain from seismic refraction profiles: The IAM-9 transect at 40 A $^{\circ} 20^{\prime}{ }^{\prime}$ '. Journal of Geophysical Research: Solid Earth 105.B3, 5859-5885. doi: $10.1029 / 1999 j b 900301$

Delgado, I. d. M.; de Souza, J. D.; da Silva, L. C.; da Silveira Filho, N. C.; dos Santos, R. A.; Pedreira, A. J.; Guimarães, J. T.; de Aquino Angelim, L. A.; Vasconcelos, A. M.; Gomes, I. P.; de Lacerda Filho, J. V.; Valente, C. R.; Perrota, M. M. \& Heineck, C. A. (2003). "Geotectônica do escudo atlântico". In: Geologia, tectônica e recursos minerais do Brasil: texto, mapas \& SIG. Ed. by Luiz Augusto Bizzi et al. Brasília: CPRM - Serviço Geológico do Brasil. Chap. V, 227-334

Dias, T. G., F. d. A. Caxito, A. C. Pedrosa-Soares, R. Stevenson, I. Dussin, L. C. d. Silva, F. Alkmim, \& M. Pimentel (2016). "Age, provenance and tectonic setting of the high-grade Jequitinhonha Complex, Araçuaí Orogen, eastern Brazil". Brazilian Journal of Geology 46.2, 199_ 219. doi: 10.1590/ 2317-4889201620160012

Dominguez, J. M. L., R. P. da Silva, A. S. Nunes, \& A. F. M. Freire (2013). "The narrow, shallow, low-accommodation shelf of central Brazil: Sedimentology, evolution, and human uses". Geomorphology 203, 46-59. doi: 10.1016/j. geomorph.2013.07.004

Dupré, S., S. Cloetingh \& G. Bertotti (2011). "Structure of the Gabon Margin from integrated seismic reflection and gravity data". Tectonophysics 506.1-4, 31-45. doi: 10.1016/j.tecto.2011.04.009

Evain, M., A. Afilhado, C. Rigoti, A. Loureiro, D. Alves, F. Klingelhöfer, P. Schnürle, A. Feld, R. Fuck, J. Soares, M. Vinicius de Lima, C. Corela, L. Matias, M. Benabdellouahed, A. Baltzer, M. Rabineau, A. Viana, M. Moulin, \& D. Aslanian (2015). "Deep structure of the Santos Basin - São Paulo Plateau System, SE Brazil”. Journal of Geophysical Research. doi: 10.1002/ 2014JB011561

Ferreira, T. S., Caixeta, J. M. \& C. Francisco. (2013). "Tectonic Evolution of the Jequitinhonha Camamu-Almada Rifted Margin”. In: XIV Simpósio nacional de estudos tectônicos

IHO-IOC GEBCO (2014). The GEBCO 2014 Grid, version 20150318

Gontijo, G. A., P. Milhomem, J. Caixeta, I. Dupuy, \& P. Menezes (2007). "Bacia de Almada". Boletim de Geociências da Petrobras 15.2, 463-473

Gordon, A. C., W. U. Mohriak, \& V. C. F. Barbosa (2012). "Crustal architecture of the Almada Basin, NE Brazil: an example of a non-volcanic rift segment of the South Atlantic passive margin". Geological Society, London, Special Publications 369.1, 215-234. doi: 10.1144/sp369.1

Hammer, P. T. C. \& R. M. Clowes (1997). "Moho reflectivity patterns - a comparison of Canadian lithoprobe transects". Tectonophysics 269.3, 179-198. doi: 10.1016/S0040-1951(96)00164-3

Hardie, L. A. (1990). "The roles of rifting and hydrothermal $\mathrm{CaCl}_{2}$ brines in the origin of potash evaporites; an hypothesis". American Journal of Science 290, 43-106. doi:10.2475/ajs.290.1.43

Hasui, Y. (2012). "Cráton São Francisco". In: Geologia do Brasil. Ed. by Y. Hasui, C. D. R. Carneiro, F. F. Marques de Almeida, \& A. Bartorelli. São Paulo: Editora Beca, 200-227. isbn: 9788562768101 
Hyndman, R. D. \& Peacock, S. M. (2003). "Serpentinization of the forearc mantle" Earth and Planetary Science Letters, 212, 417-432. doi:10.1016/s0012-821x(03)00263-2

Klingelhöfer, F., M. Evain, A. Afilhado, C. Rigoti, A. Loureiro, D. Alves, A. Leprêtre, M. Moulin, P. Schnürle, M. Benabdellouahed, A. Baltzer, M. Rabineau, A. Feld, A. Viana \& D. Aslanian (2015). "Imaging proto-oceanic crust off the Brazilian Continental Margin". Geophysical Journal International 200 (1), 471-488. doi: 10.1093/GJI/GGU387

Küchle, J., M. Holz, A. F. Brito, \& R. P. Bedregal (2005). “Análise estratigráfica de bacias rifte: aplicação de conceitos genéticos nas bacias de Camamu-Almada e Jequitinhonha". Boletim de Geociências da Petrobrás 13.2, 227-244

Lau, K. W. H., K. E. Louden, T. Funck, B. E. Tucholke, W. S. Holbrook, J. R. Hopper, \& H. Christian Larsen (2006). "Crustal structure across the Grand Banks-Newfoundland Basin Continental Margin - I. Results from a seismic refraction profile". Geophysical Journal International 167.1, 127-156. doi: 10.1111/j.1365-246x.2006.02988.x

Lavier, L. L. \& G. Manatschal (2006). "A mechanism to thin the continental lithosphere at magmapoor margins”. Nature 440.7082, 324-328. issn: 1476- 4679. doi: 10.1038/nature04608

Ledru, P., J. Eko N'Dong, V. Johan, J.-P. Prian, B. Coste, \& D. Haccard (1989). "Structural and metamorphic evolution of the Gabon Orogenic Belt: Collision tectonics in the lower proterozoic?" Precambrian Research 44.3-4, 227-241. doi: 10.1016/0301-9268(89)90046-6

Liu, Z \& N. Bleistein (1995). "Migration velocity analysis: Theory and an iterative algorithm". Geophysics 60.1, 142-153. doi: 10.1190/ 1.1443741

Loureiro, A., A. Afilhado, L. Matias, M. Moulin \& D. Aslanian (2016). "Monte Carlo approach to assess the uncertainty of wide-angle layered models: Application to the Santos Basin, Brazil". Tectonophysics 683, 286-307. doi: 10.1016/j.tecto. 2016.05.040

Ludwig, W. J., Nafe, J. E. \& C. L. Drake (1970). “Seismic refraction”. The sea 4. Part 1, 53-84

Manatschal, G., N. Froitzheim, M. Rubenach, \& B. D. Turrin (2001). "The role of detachment faulting in the formation of an ocean-continent transition: insights from the Iberia Abyssal Plain". Geological Society, London, Special Publications 187.1, 405-428. doi: 10.1144/gsl.sp.2001.187.01.20

Minshull, T. A., M. R. Muller, C. J. Robinson, R. S. White, \& M. J. Bickle (1998). "Is the oceanic Moho a serpentinization front?" Geological Society, London, Special Publications 148.1, 71-80. doi: 10.1144 /gsl.sp.1998.148.01.05

Minshull, T. A. (2009). "Geophysical characterisation of the ocean-continent transition at magmapoor rifted margins”. Comptes Rendus Geoscience, 341, 382-393 . doi: 10.1016/j.crte.2008.09.003

Moulin, M., Aslanian, D. \& P. Unternehr (2010). "A new starting point for the South and Equatorial Atlantic Ocean”. Earth-Science Reviews 98.1, 1-37. doi: 10.1016/j.earscirev.2009.08.001

Moulin, M., D. Aslanian, M. Rabineau, M. Patriat, \& L. Matias (2012). "Kinematic keys of the Santos-Namibe basins". Geological Society, London, Special Publications 369.1, 91-107. doi: $10.1144 / \mathrm{SP} 369.3$ 
Moulin, M., D. Aslanian, J.-L. Olivet, I. Contrucci, L. Matias, L. Géli, F. Klingelhöfer, H. Nouzé, J.-P. Réhault, \& P. Unternehr (2005). "Geological constraints on the evolution of the Angolan margin based on reflection and refraction seismic data (ZaïAngo project)". Geophysical Journal International 162.3, 793-810. doi: 10.1111/j.1365-246X.2005.02668.x

Moulin, M., F. Klingelhöfer, A. Afilhado, D. Aslanian, P. Schnürle, H. Nouzé, M. Rabineau, M.-O. Beslier, \& A. Feld (2015). "Deep crustal structure across a young passive margin from wide-angle and reflection seismic data (The SARDINIA Experiment) - I. Gulf of Lion's margin". Bulletin de la Société Géologique de France 186.4- 5, 309-330. doi: 10.2113/gssgfbull.186.4-5.309

Moulin, M., F. Gallais, A. Afilhado, P. Schnürle, N. A. Dias, J. Soares, R. Fuck, J.A. Cupertino, A. Viana, D. Aslanian \& Magic Team* (2016). "Imaging first steps of seafloor spreading off Maranhão-Barreirinhas-Ceará margin, NW Brazil". 48 Congresso Brasileiro de Geologia, Oct. 2016, Porto Alegre, Brazil, Sociedade Brasileira de Geologia

Poudjom Djomani, Y. H.; O'Reilly, S. Y.; Griffin, W. L. \& Morgan, P. (2001). "The density structure of subcontinental lithosphere through time". Earth and Planetary Science Letters, 184, 605-621. doi: 10.1016/S0012-821X(00)00362-9

Porada, H. (1989). "Pan-African rifting and orogenesis in southern to equatorial Africa and eastern Brazil”. Precambrian Research 44.2, 103-136. doi: 10.1016/0301-9268(89)90078-8

Prodehl, C., B. Kennett, I. M. Artemieva, \& H. Thybo (2013). "100 years of seismic research on the Moho”. Tectonophysics 609, 9-44. doi: 10.1016/j.tecto.2013.05.036

Rangel, H., J. Oliveira \& J. Caixeta (2007). "Bacia de Jequitinhonha". Boletim de Geociências da Petrobras $15,475-483$

Rosendahl, B. R., H. Groschel-Becker, J. Meyers, \& K. Kaczmarick (1991). "Deep seismic reflection study of a passive margin, southeastern Gulf of Guinea". Geology 19.4, 291-295. doi: 10.1130/0091-7613(1991)019<0291:dsrsoa>2.3.co;2

Sandwell, D. T. \& W. H. F. Smith (2009). "Global marine gravity from retracked Geosat and ERS-1 altimetry: Ridge segmentation versus spreading rate". Journal of Geophysical Research 114.B1, 118. doi: 10. 1029/2008jb006008

Sandwell, D. T., E. Garcia, K. Soofi, P. Wessel, M. Chandler, \& W. H. F. Smith (2013). "Toward 1mGal accuracy in global marine gravity from CryoSat-2, Envisat, and Jason-1". The Leading Edge 32.8, 892- 899. doi: 10.1190/tle32080892.1

Sandwell, D. T., R. D. Müller, W. H. F. Smith, E. Garcia, \& R. Francis (2014). "New global marine gravity model from CryoSat- 2 and Jason-1 reveals buried tectonic structure". Science 346.6205, 65- 67. doi: 10.1126/science. 1258213

Schobbenhaus, C. \& B. B. de Brito Neves (2003). "A Geologia do Brasil no Contexto da Plataforma Sul-Americana”. In: Geologia, tectônica e recursos minerais do Brasil: texto, mapas \& SIG. Ed. by Luiz Augusto Bizzi et al. Brasília: CPRM - Serviço Geológico do Brasil. Chap. I, 5-54

Scotchman, I. \& D. Chiossi (2009). "Kilometre-scale uplift of the Early Cretaceous rift section, Camamu Basin". In Proceedings of the AAPG International Conference and Exhibition, Cape Town 
Stockwell, J. W. (1999). "The CWP/SU: Seismic Un*x package". Computers \& Geosciences 25.4, 415-419. issn: 0098-3004. doi: 10.1016/s0098-3004(98)00145-9

Thybo, H., T. Janik, V. D. Omelchenko, M. Grad, R.G. Garetsky, A.A. Belinsky, G. I. Karatayev, G. Zlotski, M. E. Knudsen, R. Sand, J. Yliniemi, T. Tiira, U. Luosto, K. Komminaho, R. Giese, A. Guterch, C.-E. Lund, O. M. Kharitonov, T. Ilchenko, D. V. Lysynchuk, V .M. Skobelev, J. J. Doody (2003). "Upper lithospheric seismic velocity structure across the Pripyat Trough and the Ukrainian Shield along the EUROBRIDGE'97 profile". Tectonophysics 371.1-4, 41-79. doi: 10.1016/s00401951(03)00200-2

Thybo, H. \& I. M. Artemieva (2013). "Moho and magmatic underplating in continental lithosphere". Tectonophysics 609, 605-619. doi: 10.1016/ J.TECTO.2013.05.032

Trompette, R. (1997). "Neoproterozoic ( $\square 600 \mathrm{Ma}$ ) aggregation of Western Gondwana: a tentative scenario". Precambrian Research 82.1, 101-112. doi: 10.1016/S0301-9268(96)00045-9

Wannesson, J., J.-C. Icart, \& J. Ravat (1991). "Structure and evolution of adjoining segments of the West African margin determined from deep seismic profiling". Geodynamics Series, 275-289. issn: 0277-6669. doi: 10.1029/ gd022p0275

Wessel, P. \& W. H. F. Smith (1996). "A global, self-consistent, hierarchical, high-resolution shoreline”. Journal of Geophysical Research 101, 8741-8743. doi: 10.1029/ 96JB00104

Wessel, P. \& W. H. F. Smith (1998). "New, improved version of Generic Mapping Tools released". Eos, Transactions American Geophysical Union 79.47, 579-579. doi: 10.1029/ 98EO00426

White, R. S., McKenzie, D. \& R. K O’Nions. (1992). “Oceanic crustal thickness from seismic measurements and rare earth element inversions". Journal of Geophysical Research: Solid Earth (1978-2012) 97.B13, 19683-19715. doi: 10.1029/92JB01749

Whitmarsh, R. B., R. S. White, S. J. Horsefield, J.-C. Sibuet, M. Recq, \& V. Louvel (1996). "The ocean-continent boundary off the western continental margin of Iberia: Crustal structure west of Galicia Bank". Journal of Geophysical Research: Solid Earth 101.B12, 28291-28314. doi: 10.1029/96JB02579

Zelt, C. A. (1999). "Modelling strategies and model assessment for wide-angle seismic traveltime data". Geophysical Journal International 139.1, 183-204. doi: 10.1046/J.1365-246X.1999.00934.X

Zelt, C. A. \& D. A. Forsyth (1994). "Modeling wide-angle seismic data for crustal structure: Southeastern Grenville Province". Journal of Geophysical Research: Solid Earth (1978-2012) 99.B6, 11687-11704. doi: 10.1029/ 93JB02764

Zelt, C. A. \& R. B. Smith (1992). "Seismic traveltime inversion for 2-D crustal velocity structure". Geophysical Journal International 108.1, 16- 34. doi: 10.1111/J.1365-246X.1992.TB00836.X 
Figure 1: Location of profiles of the SALSA mission. a) satellite-derived gravimetric anomaly in the sea (Sandwell \& Smith, 2009; Sandwell et al., 2013, 2014) and topography on land (IHO-IOC GEBCO, 2014). Circles denote OBS deployments. Triangles denote land stations. Black solid lines indicate MCS sections. Dashed black line denotes faults. Dashed white lines indicate marine basin limits (Bizzi et al., 2003). Orange area indicates the Recôncavo-Tucano-Jatobá (RTJ) basins (Bizzi et al., 2003). Light blue area indicates the limits of the São Francisco Craton, adapted from (Hasui, 2012). TMAZ: Taipus-Mirim Accommodation Zone. Main river indicated by solid blue lines (Wessel \& Smith, 1996). b) Bathymetry (IHO-IOC GEBCO, 2014) around the profiles discussed in the present paper. c) General location map of studied area and conjugate margin. 
Figure 2: MCS record sections for: a) SALSA10, b) SALSA12, and c) SALSA11. Solid coloured lines indicate the modelled interfaces. White triangles denote OBS locations. Red vertical line indicates crossings with other profiles. 
Figure 3: Instrument SL11OBS05. a) Record section. b) Synthetic record section. c) Synthetic record section with arrivals coloured according to their identified phases. d) Picked arrivals coloured according to phase, their error bars, and solid black lines indicating the predicted arrival times. e) Ray tracing over the model. f) Comparison with the MCS section, coloured lines match the reflected arrivals colours from d) and colour scale from Fig. 2 . All time sections reduced to $7 \mathrm{~km} / \mathrm{s}$. 
Figure 4: Instrument SL11OBS09. a) Record section. b) Synthetic record section. c) Synthetic record section with arrivals coloured according to their identified phases. d) Picked arrivals coloured according to phase, their error bars, and solid black lines indicating the predicted arrival times. e) Ray tracing over the model. f) Comparison with the MCS section, coloured lines match the reflected arrivals colours from d) and colour scale from Fig. 2. All time sections reduced to $7 \mathrm{~km} / \mathrm{s}$. 
Figure 5: Instrument SL11OBS13. a) Record section. b) Synthetic record section. c) Synthetic record section with arrivals coloured according to their identified phases. d) Picked arrivals coloured according to phase, their error bars, and solid black lines indicating the predicted arrival times. e) Ray tracing over the model. f) Comparison with the MCS section, coloured lines match the reflected arrivals colours from d) and colour scale from Fig. 2 . All time sections reduced to $7 \mathrm{~km} / \mathrm{s}$. 
Figure 6: Instrument SL12OBS12. a) Record section. b) Synthetic record section. c) Synthetic record section with arrivals coloured according to their identified phases. d) Picked arrivals coloured according to phase, their error bars, and solid black lines indicating the predicted arrival times. e) Ray tracing over the model. f) Comparison with the MCS section, coloured lines match the reflected arrivals colours from d) and colour scale from Fig. 2 . All time sections reduced to $7 \mathrm{~km} / \mathrm{s}$. 
Figure 7: Instrument SL12OBS09. a) Record section. b) Synthetic record section. c) Synthetic record section with arrivals coloured according to their identified phases. d) Picked arrivals coloured according to phase, their error bars, and solid black lines indicating the predicted arrival times. e) Ray tracing over the model. f) Comparison with the MCS section, coloured lines match the reflected arrivals colours from d) and colour scale from Fig. 2. All time sections reduced to $7 \mathrm{~km} / \mathrm{s}$. 
Figure 8: Final velocity models for profiles: a) SL10, b) SL12, and c) SL11. Thick blue lines indicate interfaces constrained by wide-angle reflections. Shaded areas indicate ray coverage. Observed (dashed black lines) and calculated (solid red lines) gravity anomalies under each profile. 
Figure 9: Pre-stack depth migrated MCS record sections for: a) SALSA11, c) SALSA10, and e) SALSA12. RMO analysis of the pre-stack depth migrated MCS record sections of: b) SALSA11, d) SALSA10, and f) SALSA12. Solid coloured lines indicate the modelled interfaces. White triangles denote OBS locations. Red vertical line indicates crossings with other profiles. 
Figure 10: Comparison of 1D velocity depth profiles at the crossings of SL11 (black solid lines) and SL12 (purple solid lines) with SL10 (blue dashed line). Coloured regions show uncertainties estimated with VMONTECARLO for a) SL12; b) SL11; c) SL10 at the crossing with SL11; d) SL10 at the crossing with SL12. Different colours indicate normalized random model scores. 
Figure 11: Model resolution for all velocity nodes of: a) SL11, b) SL12, and c) SL10. Gray and yellow areas are considered well resolved in terms of velocities. Squares indicated well-resolved depth nodes in the basement. 
Figure 12: a) and b): Model uncertainties for profile SL10, using 5116 models that were capable of tracing at least $85 \%$ of the rays of the preferred model, with a maximum residual of $210 \mathrm{~ms}$ and a $\chi^{2}$ value of 4.4. c) and d): Model uncertainties for profile SL11, using 16289 models that were at least as good as the preferred model. e) and f) Model uncertainties for profile SL12, using 15324 models that were at least as good as the preferred model. Red shades [a), c) and d)] denote maximum admissible velocity increases from the preferred solution. Blue shades [b), $d$ and $f$ )] denote maximum admissible velocity decreases from the preferred solution. Yellow bands indicate interface depth uncertainties resulting from the increase of propagation velocity [a), c) and e)], and from the decrease of propagation velocity [b), d) and f)]. 
Figure 13: Overlay of SL11 model (dashed lines) to line-drawing of ION GXT-1900 (solid lines). Blue arrow marks crossing with profile SL10. Inset shows the coincident tracks of SL11 and ION GXT-1900 profiles. 
Figure 14: Cartoon for the boudinage of the lower continental crust as it is stretched and enriched during the rifting process. 
Figure 15: 1D velocity-depth profiles below the basement of SL11, taken at $10 \mathrm{~km}$ intervals. Interfaces identified by thick coloured lines have a velocity contrast over $0.1 \mathrm{~km} / \mathrm{s}$. Interfaces identified by thin grey lines have velocity contrast under $0.1 \mathrm{~km} / \mathrm{s}$. Blue regions indicate a compilation of 1D velocity-depth profiles from (White et al., 1992) for oceanic crusts in the Atlantic Ocean aged $59 \mathrm{Ma}$ to $127 \mathrm{Ma}$ and $142 \mathrm{Ma}$ to $170 \mathrm{Ma}$. Pink regions indicate a compilation of continental crusts (Christensen \& Mooney, 1995). Green 1D profiles mark thinned continental crust, orange profiles mark exhumed lower crust. 
Figure 16: 1D velocity-depth profiles below the basement of SL12, taken at $10 \mathrm{~km}$ intervals. Interfaces identified by thick coloured lines have a velocity contrast over $0.1 \mathrm{~km} / \mathrm{s}$. Interfaces identified by thin grey lines have velocity contrast under $0.1 \mathrm{~km} / \mathrm{s}$. Blue regions indicate a compilation of 1D velocity-depth profiles from (White et al., 1992) for oceanic crusts in the Atlantic Ocean aged $59 \mathrm{Ma}$ to $127 \mathrm{Ma}$ and $142 \mathrm{Ma}$ to $170 \mathrm{Ma}$. Pink regions indicate a compilation of continental crusts (Christensen \& Mooney, 1995). Green 1D profiles mark thinned continental crust, orange profiles mark exhumed lower crust. 
Figure 17: 1D velocity-depth profiles below the basement of SL10, taken at $10 \mathrm{~km}$ intervals. Blue regions indicate a compilation of 1D velocity-depth profiles from White et al. (1992) for oceanic crusts in the Atlantic Ocean aged 59 Ma to $127 \mathrm{Ma}$ and $142 \mathrm{Ma}$ to $170 \mathrm{Ma}$. Pink regions indicate a compilation of continental crusts (Christensen \& Mooney, 1995). Red and green profiles are from the thinned continental crust domain, purple profiles are from the transitional domain. Black profiles are from both domains. 
Figure 18: Comparison between 1D basement velocity-depth profiles of SL11 and SL12, extracted every $10 \mathrm{~km}$ after the necking zone (orange lines), of SL10, in the Camamu-Almada basin (purple lines), and from wide-angle seismic models where ocean-transition zones were interpreted as exhumed and/or serpentinized upper mantle (shaded areas): a) IAM-9 in Iberia Abyssal Plain (Dean et al., 2000); b) SCREECH-2 in the Grand Banks margin, offshore Newfoundland (van Avendonk et al., 2006); c) CAM in the Southern Galician margin (Chian et al., 1999); d) Mean velocity-depth variations with one standard deviation above and below the mean of SCREECH-1, SCREECH-2, SCREECH-3, WAM, ISE-1, CAM-144 and IAM-9 models from Minshull (2009). Same comparison, but where ocean-transition zones were interpreted as exhumed lower continental crust (shaded areas) e) Sardinia profiles in the Provençal Basin (Moulin et al., 2015); f) SanBa Experiment in Santos Basin (Evain et al., 2015). 
Table 1: Details of profiles SL10, SL11 and SL12. 
Table 2: Vp Propagation velocities of SL11, in $\mathrm{km} / \mathrm{s}$. Velocities are specified at the top and bottom of each layer for the proximal and distal parts of the basin. 
Table 3: Statistics for model SL11. 
Table 4: Vp Propagation velocities of SL12, in $\mathrm{km} / \mathrm{s}$. Velocities are specified at the top and bottom of each layer for the proximal and distal parts of the basin. 
Table 5: Statistics for model SL12. 
Table 6: Vp Propagation velocities of SL10, in $\mathrm{km} / \mathrm{s}$. Velocities are specified at the top and bottom of each layer. 
Table 7: Statistics for model SL10. 
Table 8: Densities converted from seismic propagation velocities for SL10, SL11 and SL12, according to Ludwig et al. (1970). 


$\begin{array}{llll}\text { Profile } & \text { Maximum offset }(\mathrm{km}) & \text { OBS } & \text { No. of shots } \\ \text { SL10 } & 230 & 15 & 1686 \\ \text { SL11 } & 180 & 15 & 1161 \\ \text { SL12 } & 215 & 12 \text { (1 lost) } & 1399\end{array}$

Table 1: Details of profiles SL10, SL11 and SL12. 


\begin{tabular}{|c|c|c|}
\hline Layer & Proximal & Distal \\
\hline \multirow[t]{2}{*}{ Ps1 } & \multicolumn{2}{|c|}{1.8} \\
\hline & \multicolumn{2}{|c|}{1.9} \\
\hline Ps2 & 2.2 & 2 \\
\hline \multirow{2}{*}{ Ps3 } & \multicolumn{2}{|c|}{2.6} \\
\hline & \multicolumn{2}{|c|}{2.7} \\
\hline \multirow{2}{*}{ Ps4 } & 2.8 & 2.6 \\
\hline & 2.9 & 2.7 \\
\hline \multirow{2}{*}{ Ps5 } & 3 & 2.7 \\
\hline & 3 & 2.8 \\
\hline \multirow{2}{*}{ Ps6 } & 4.1 & 3.1 \\
\hline & 4.2 & 3.2 \\
\hline \multirow{2}{*}{ Ps7 } & 4.4 & 4.3 \\
\hline & 4.5 & 4.7 \\
\hline \multirow{2}{*}{ Ps8 } & 4.9 & 4.7 \\
\hline & \multicolumn{2}{|c|}{5} \\
\hline \multirow{2}{*}{ C1 } & 5.2 & - \\
\hline & 5.3 & - \\
\hline \multirow{2}{*}{$\mathrm{C} 2$} & 5.6 & 5.8 \\
\hline & 6.1 & 6.4 \\
\hline \multirow{2}{*}{ C3 } & 6.4 & 6.3 \\
\hline & 6.8 & 6.8 \\
\hline \multirow{2}{*}{$A \vee Z$} & \multicolumn{2}{|c|}{7.6} \\
\hline & \multicolumn{2}{|c|}{8.1} \\
\hline \multirow{2}{*}{ M1 } & 8.1 & 8.2 \\
\hline & \multicolumn{2}{|c|}{8.3} \\
\hline
\end{tabular}

Table 2: Vp Propagation velocities of SL11, in $\mathrm{km} / \mathrm{s}$. Velocities are specified at the top and bottom of each layer for the proximal and distal parts of the basin. 


\begin{tabular}{cccc} 
& & \multicolumn{2}{c}{ ACCEPTED } \\
Phase & No. of Points & RMS (s) & $X^{2}$ \\
Pw & 5538 & 0.042 & 0.739 \\
Ps2P & 513 & 0.043 & 0.113 \\
Ps2 & 633 & 0.077 & 1.357 \\
Ps3P & 417 & 0.026 & 0.045 \\
Ps3 & 209 & 0.038 & 0.922 \\
Ps4P & 248 & 0.014 & 0.034 \\
Ps4 & 72 & 0.048 & 0.695 \\
Ps5P & 365 & 0.038 & 0.08 \\
Ps6P & 76 & 0.019 & 0.011 \\
Ps6 & 226 & 0.046 & 1.753 \\
Ps7P & 257 & 0.036 & 0.126 \\
Ps7 & 288 & 0.037 & 0.942 \\
Ps8P & 444 & 0.05 & 0.188 \\
Ps8 & 916 & 0.048 & 0.859 \\
Pg1P & 165 & 0.075 & 0.91 \\
Pg1 & 469 & 0.044 & 0.496 \\
Pg2P & 530 & 0.052 & 0.372 \\
Pg2 & 446 & 0.098 & 2.872 \\
Pg3P & 258 & 0.06 & 0.631 \\
Pg3 & 1739 & 0.106 & 2.616 \\
Pu1P & 994 & 0.103 & 2.209 \\
Pu1 & 808 & 0.113 & 1.776 \\
PmP & 902 & 0.086 & 0.679 \\
Pn & 2288 & 0.072 & 0.511 \\
Global & 18801 & 0.068 & 1.002 \\
& & & \\
& & &
\end{tabular}

Table 3: Statistics for model SL11. 


\begin{tabular}{|c|c|c|}
\hline Layer & Proximal & Distal \\
\hline \multirow{2}{*}{ Ps1 } & \multicolumn{2}{|c|}{1.8} \\
\hline & \multicolumn{2}{|c|}{1.9} \\
\hline \multirow{2}{*}{ Ps2 } & 2.3 & 2 \\
\hline & 2.4 & 2.1 \\
\hline \multirow{2}{*}{ Ps3 } & \multicolumn{2}{|c|}{2.6} \\
\hline & \multicolumn{2}{|c|}{2.7} \\
\hline \multirow{2}{*}{ Ps4 } & 3.8 & 3.6 \\
\hline & 3.9 & 3.7 \\
\hline \multirow{2}{*}{ Ps5 } & \multicolumn{2}{|c|}{3.8} \\
\hline & \multicolumn{2}{|c|}{3.9} \\
\hline \multirow{2}{*}{ Ps6 } & 4.1 & 4.3 \\
\hline & 4.3 & 4.4 \\
\hline \multirow{2}{*}{ Ps7 } & 4.4 & 4.5 \\
\hline & 4.4 & 4.7 \\
\hline \multirow{2}{*}{ Ps8 } & \multicolumn{2}{|c|}{5.1} \\
\hline & \multicolumn{2}{|c|}{5.2} \\
\hline \multirow{2}{*}{ C1 } & \multicolumn{2}{|c|}{5.2} \\
\hline & \multicolumn{2}{|c|}{5.3} \\
\hline \multirow{2}{*}{$\mathrm{C} 2$} & 6.7 & 7 \\
\hline & 7.2 & 7.2 \\
\hline \multirow{2}{*}{ C3 } & 7.2 & - \\
\hline & 7.3 & - \\
\hline \multirow{2}{*}{ M1 } & \multicolumn{2}{|c|}{8} \\
\hline & \multicolumn{2}{|c|}{8.3} \\
\hline
\end{tabular}

Table 4: Vp Propagation velocities of SL12, in $\mathrm{km} / \mathrm{s}$. Velocities are specified at the top and bottom of each layer for the proximal and distal parts of the basin. 


\begin{tabular}{cccc} 
& & \multicolumn{2}{c}{ ACCEPTED } \\
Phase & No. of Points & RMS (s) & $X^{2}$ \\
Pw & 3454 & 0.041 & 0.734 \\
Ps2P & 194 & 0.032 & 0.04 \\
Ps2 & 288 & 0.031 & 0.391 \\
Ps3P & 414 & 0.042 & 0.304 \\
Ps3 & 163 & 0.076 & 1.223 \\
Ps4P & 267 & 0.083 & 0.505 \\
Ps4 & 331 & 0.072 & 1.561 \\
Ps5P & 162 & 0.047 & 0.168 \\
Ps6P & 27 & 0.009 & 0.004 \\
Ps6 & 226 & 0.06 & 1.367 \\
Ps7P & 274 & 0.065 & 0.307 \\
Ps7 & 70 & 0.04 & 1.358 \\
Ps8P & 153 & 0.083 & 1.456 \\
Ps8 & 540 & 0.051 & 0.98 \\
Pg1P & 240 & 0.056 & 0.457 \\
Pg1 & 767 & 0.058 & 0.972 \\
Pg2P & 407 & 0.085 & 1.106 \\
Pg2 & 2826 & 0.073 & 0.937 \\
Pg3P & 990 & 0.08 & 1.102 \\
PmP & 37 & 0.066 & 0.251 \\
Pn & 1304 & 0.057 & 0.371 \\
Global & 13134 & 0.061 & 0.794 \\
PmP & 902 & 0.086 & 0.679 \\
Pn & 2288 & 0.072 & 0.511 \\
Global & 18801 & 0.068 & 1.002 \\
& & & \\
& & &
\end{tabular}

Table 5: Statistics for model SL12. 


\begin{tabular}{|c|c|c|}
\hline Layer & Almada-Camamu & Jequitinhonha \\
\hline \multirow[t]{2}{*}{ Ps1 } & \multicolumn{2}{|c|}{1.9} \\
\hline & \multicolumn{2}{|c|}{2} \\
\hline \multirow{2}{*}{ Ps2 } & \multicolumn{2}{|c|}{2.3} \\
\hline & \multicolumn{2}{|c|}{2.4} \\
\hline \multirow{2}{*}{ Ps3 } & 2.6 & 2.4 \\
\hline & 2.8 & 2.7 \\
\hline \multirow{2}{*}{ Ps4 } & $3.8-4.2$ & 4.2 \\
\hline & \multicolumn{2}{|c|}{4.3} \\
\hline \multirow{2}{*}{ Ps5 } & \multicolumn{2}{|c|}{4.3} \\
\hline & 4.8 & 4.4 \\
\hline \multirow{2}{*}{ C1 } & 5 & 5.3 \\
\hline & 5.7 & 5.6 \\
\hline \multirow{2}{*}{$\mathrm{C} 2$} & \multicolumn{2}{|c|}{5.8} \\
\hline & \multicolumn{2}{|c|}{6} \\
\hline \multirow{2}{*}{ C3 } & \multicolumn{2}{|c|}{6.6} \\
\hline & \multicolumn{2}{|c|}{7} \\
\hline \multirow{2}{*}{ M1 } & \multicolumn{2}{|c|}{8.1} \\
\hline & \multicolumn{2}{|c|}{8.2} \\
\hline
\end{tabular}

Table 6: Vp Propagation velocities of SL10, in $\mathrm{km} / \mathrm{s}$. Velocities are specified at the top and bottom of each layer. 


$\begin{array}{cccc}\text { Phase } & \text { No. of Points } & \text { RMS }(\mathrm{s}) & \mathrm{X}^{2} \\ \text { Pw } & 1032 & 0.012 & 0.015 \\ \text { Ps1P } & 236 & 0.085 & 0.726 \\ \text { Ps1 } & 399 & 0.141 & 1.981 \\ \text { Ps2P } & 517 & 0.087 & 0.751 \\ \text { Ps2 } & 51 & 0.244 & 6.064 \\ \text { Ps3P } & 341 & 0.143 & 2.048 \\ \text { Ps3 } & 816 & 0.178 & 3.183 \\ \text { Ps4P } & 87 & 0.13 & 1.699 \\ \text { Ps4 } & 232 & 0.048 & 0.236 \\ \text { Pg1P } & 1299 & 0.138 & 1.916 \\ \text { Pg2 } & 2577 & 0.157 & 2.457 \\ \text { PmP } & 1803 & 0.136 & 1.857 \\ \text { Pn } & 3579 & 0.122 & 1.484 \\ \text { Global } & 12969 & 0.132 & 1.742\end{array}$

Table 7: Statistics for model SL10. 


$\begin{array}{cccc} & \text { ACCEPTED } & \text { MANUSCRIPT } \\ \text { Domain } & \text { SL10 } & \text { SL11 } & \text { SL12 } \\ \text { Sediments } & 2200-2580 & 2200-2520 & 2200-2540 \\ \text { Crust } & 2660-2880 & 2530-3250 & 2680-3030 \\ \text { Upper Mantle } & 3330 & 3320-3330 & 3320-3330\end{array}$

Table 8: Densities converted from seismic propagation velocities for SL10, SL11 and SL12, according to Ludwig et al. (1970). 


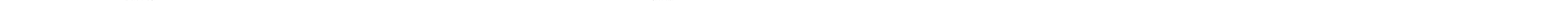




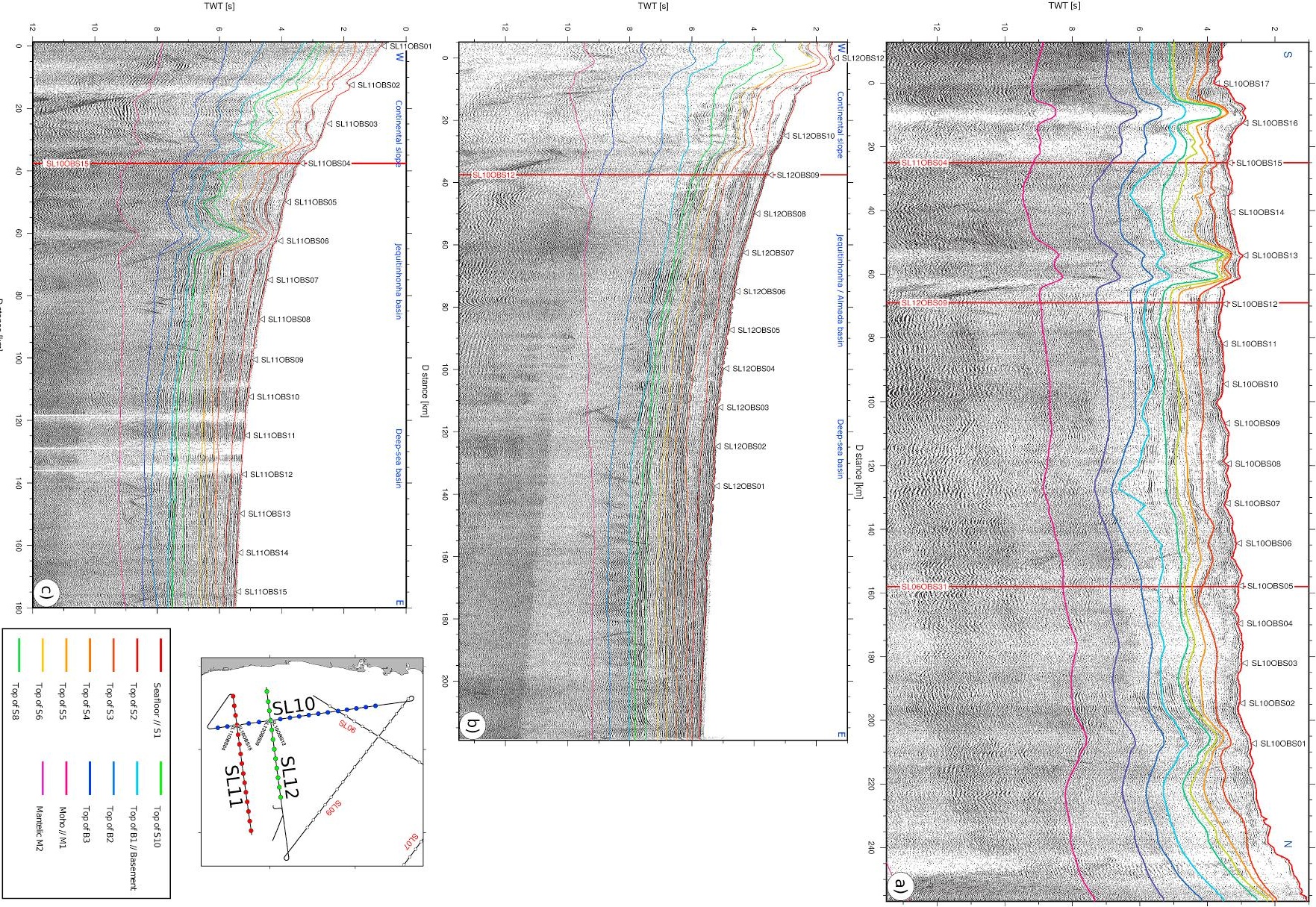



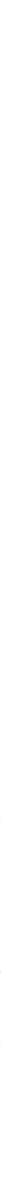
$-20$

$-40$

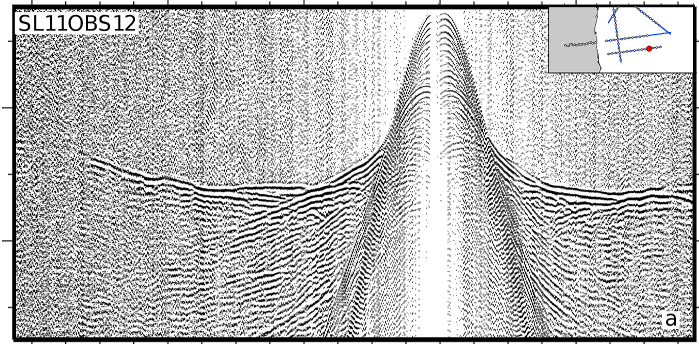

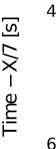

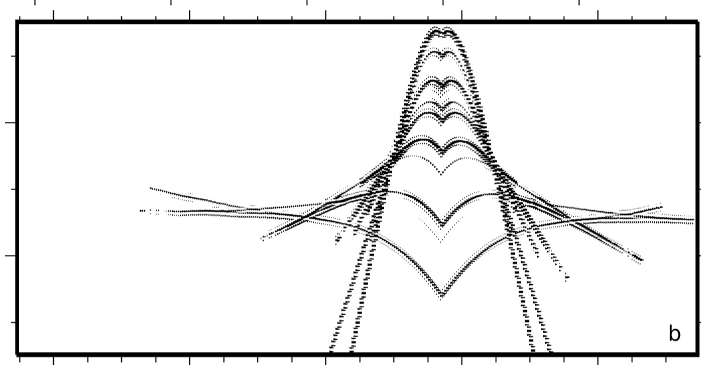

6

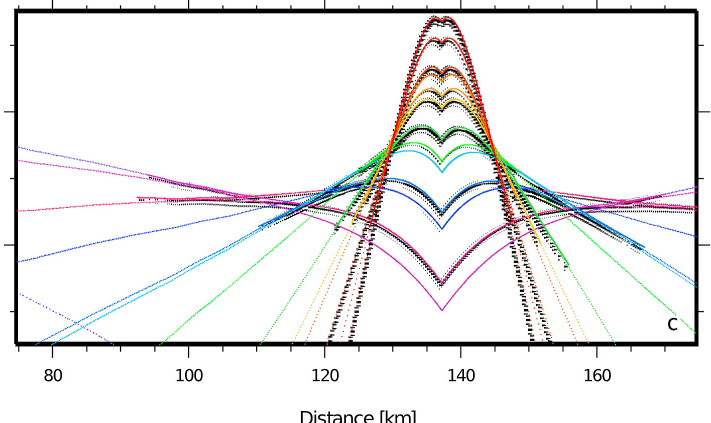

Offset [km]

$-20$

0

$0 \quad 20$

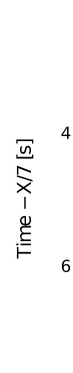

$\mathrm{E}$
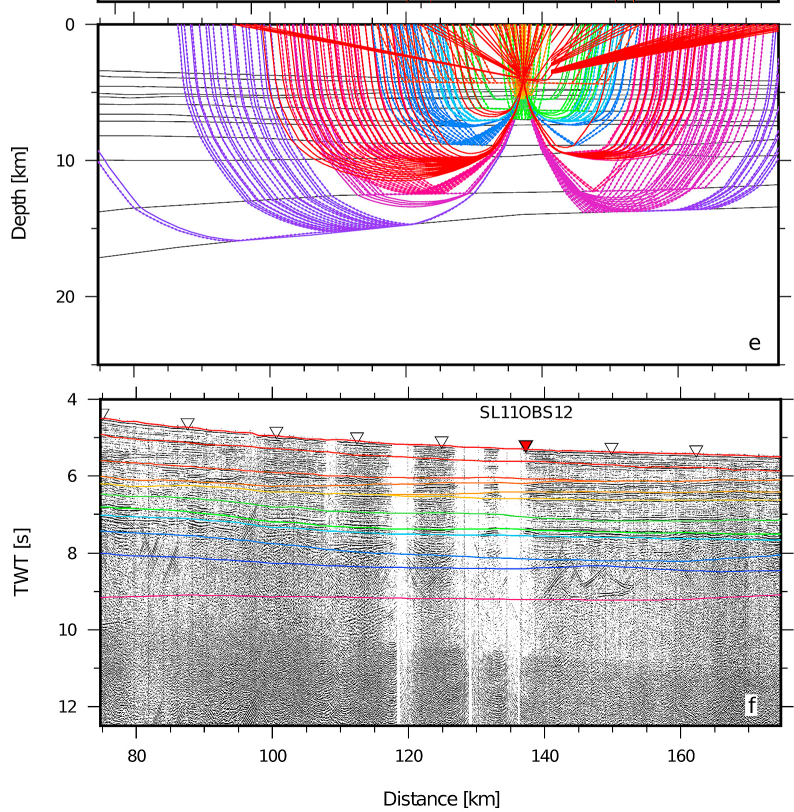


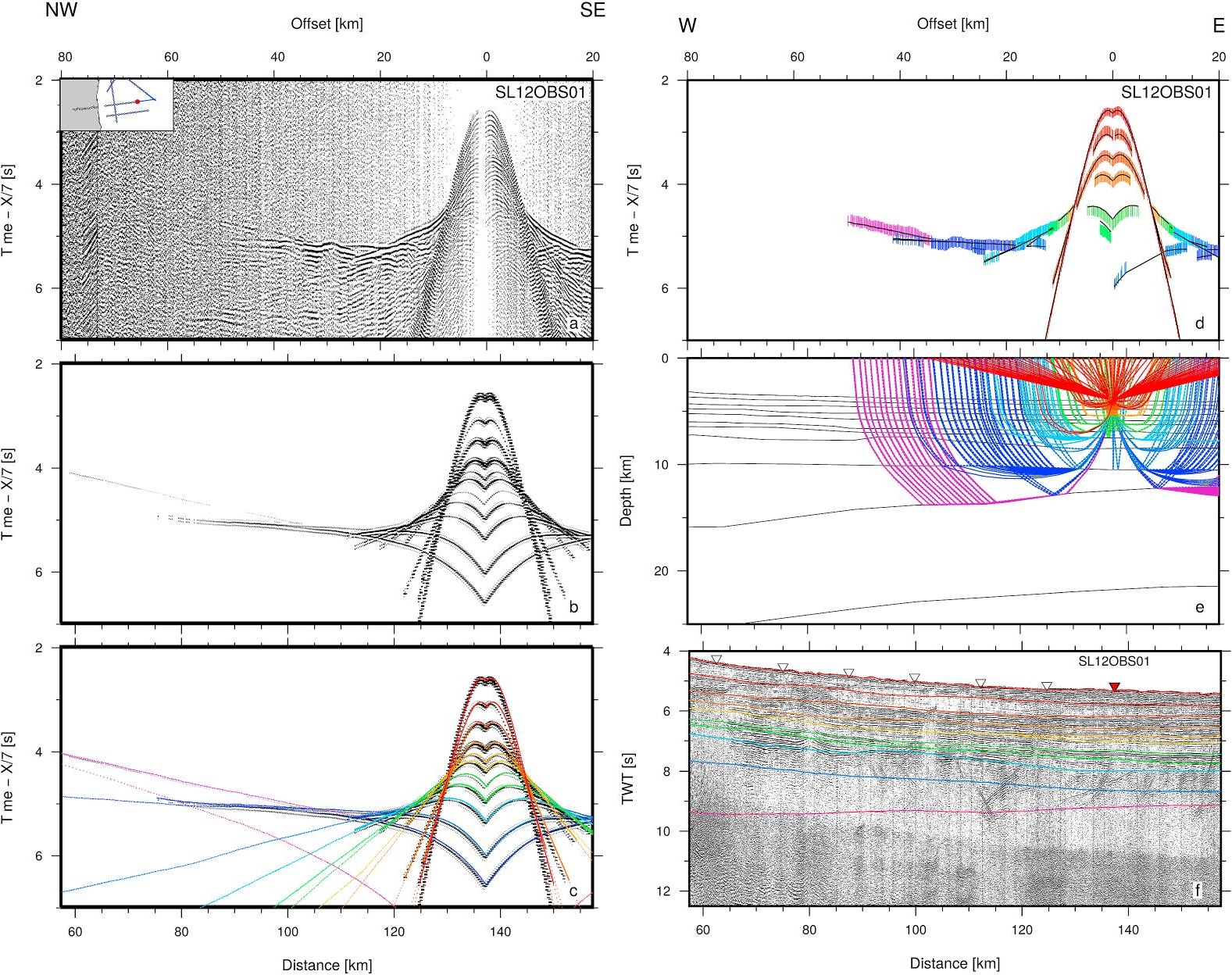




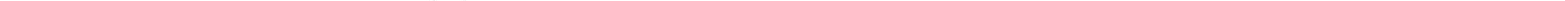



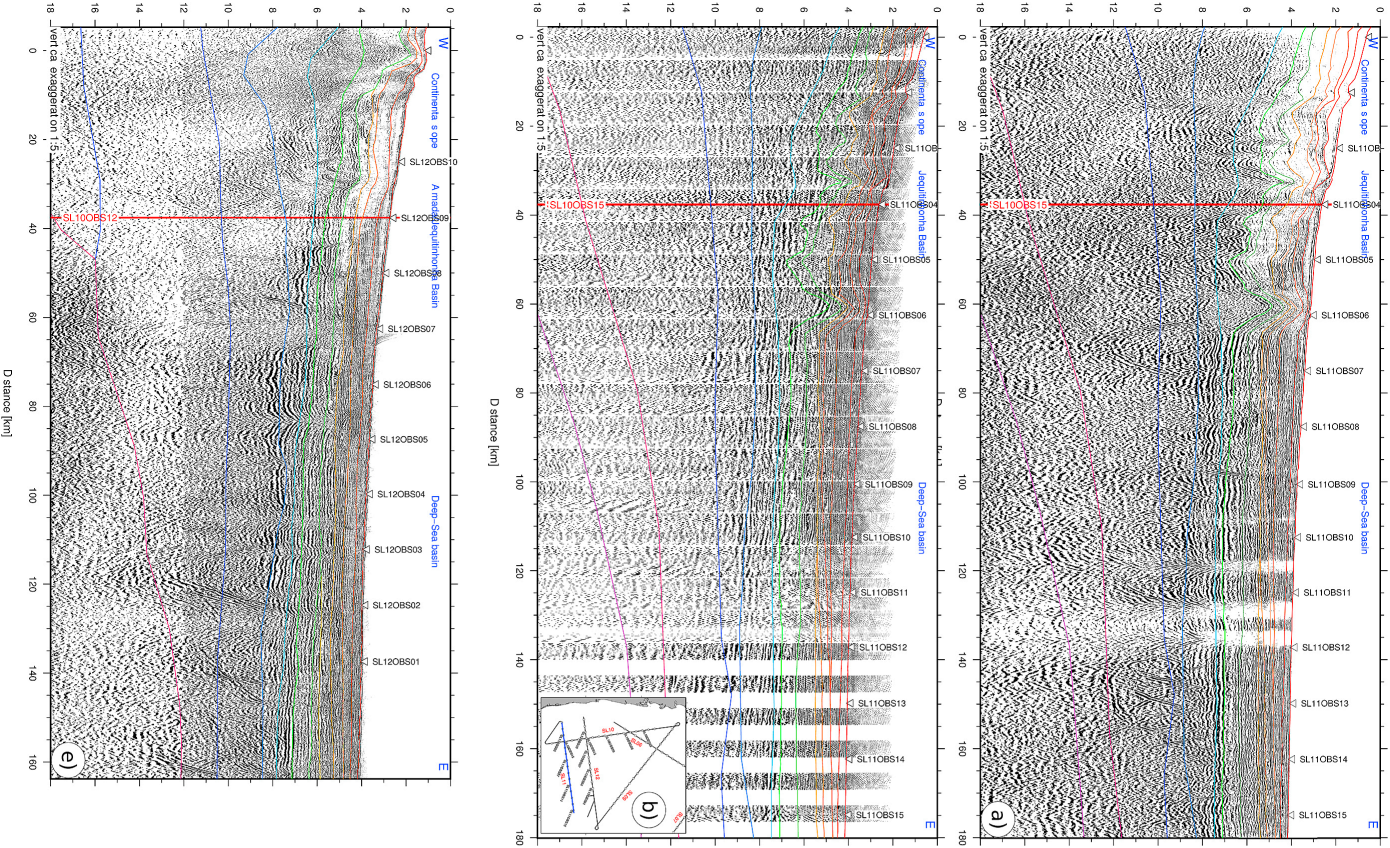

Depth [km]
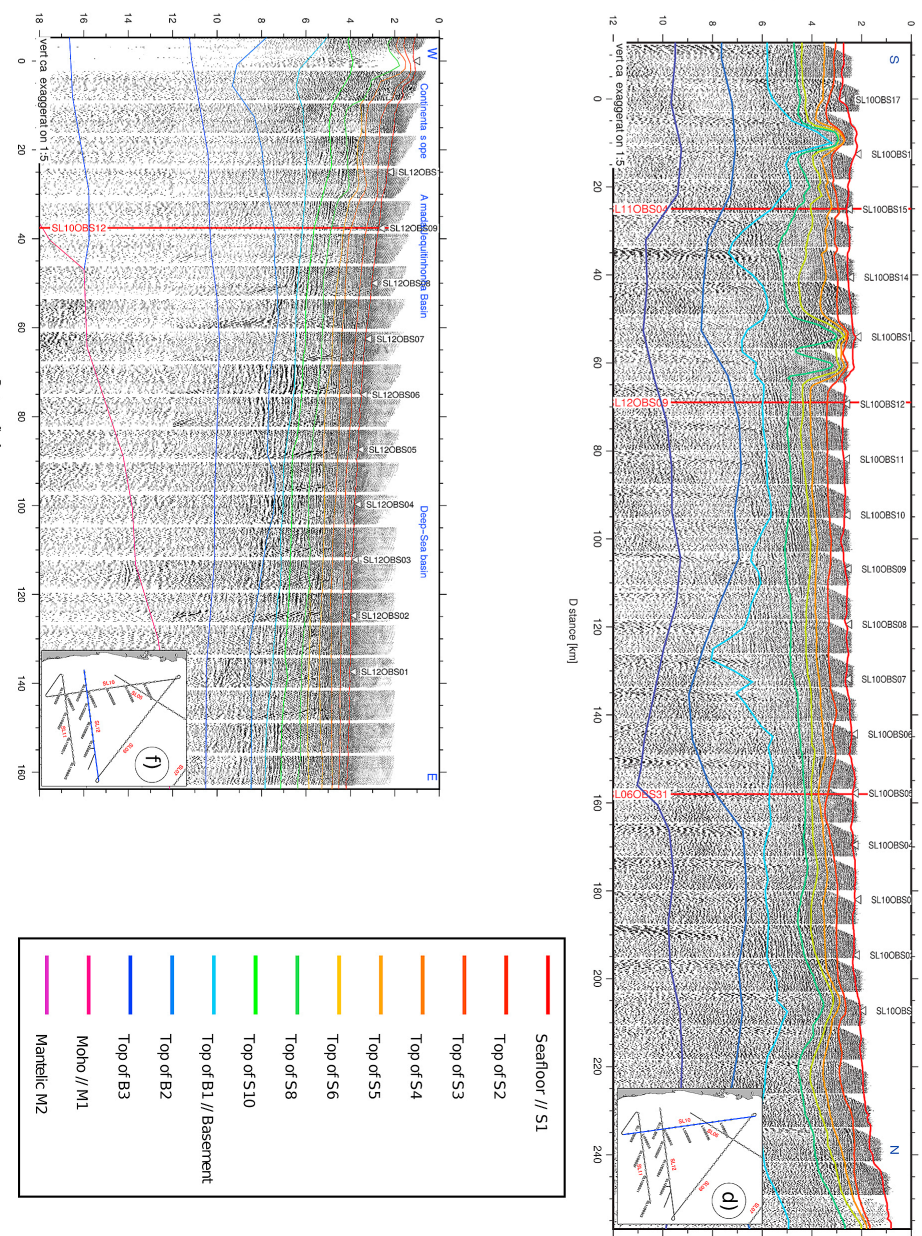

Depth [km]

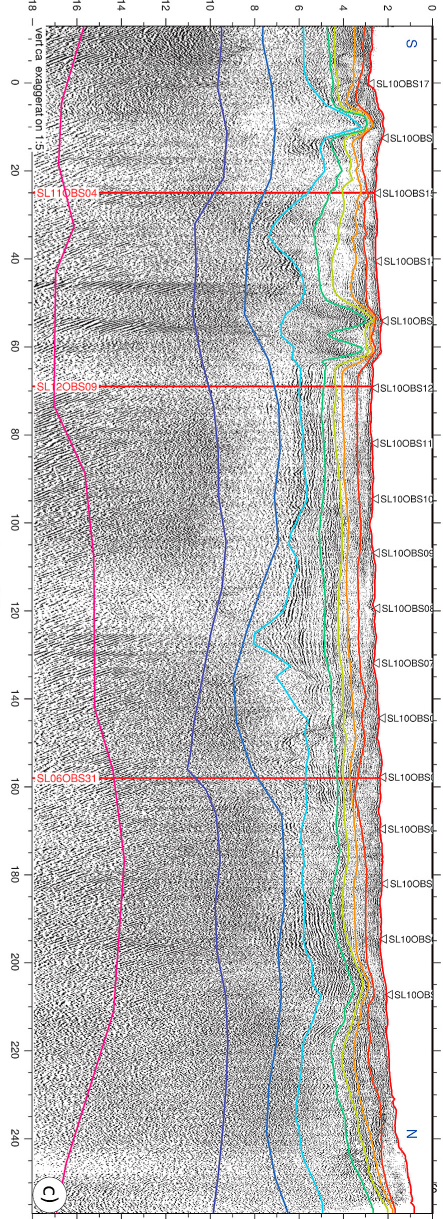


$V p[\mathrm{~km} / \mathrm{s}]$

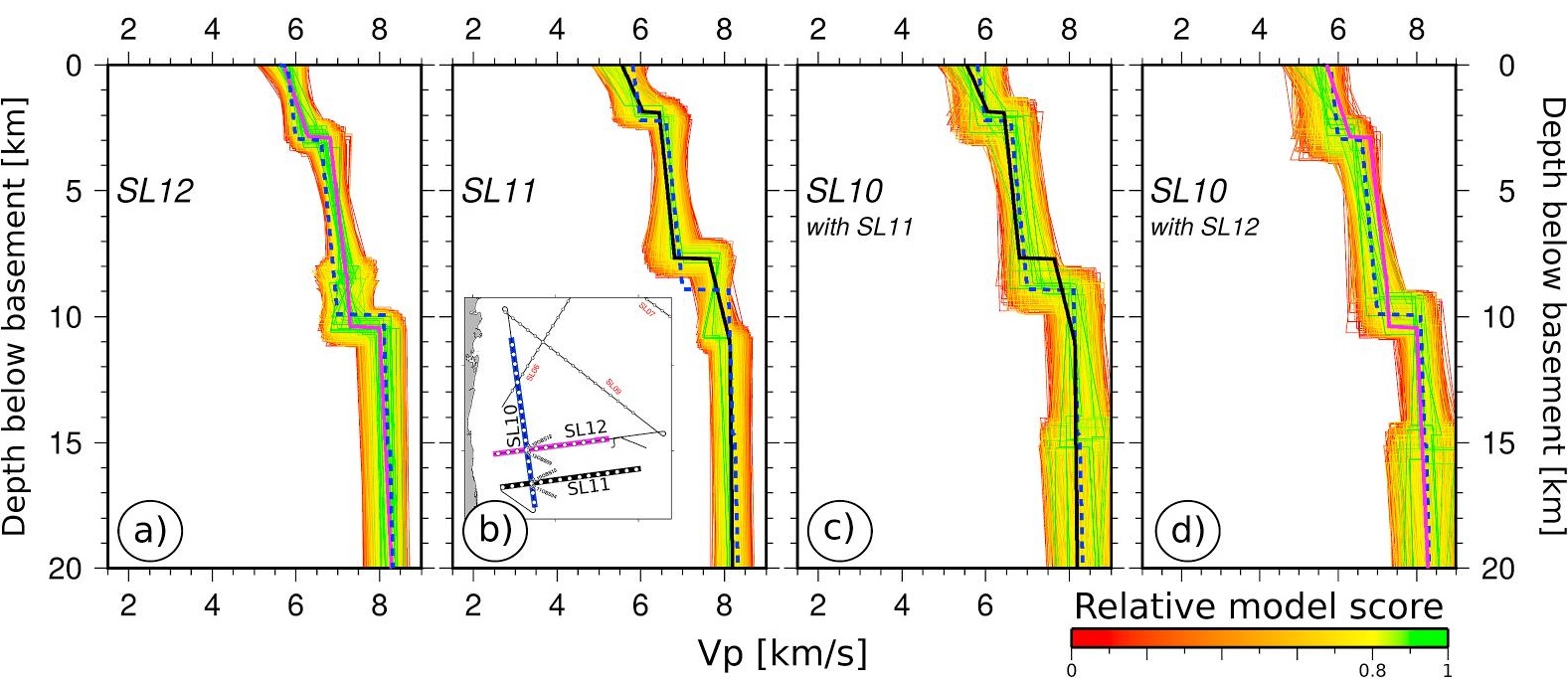




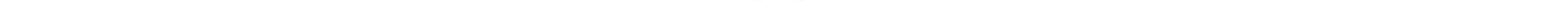



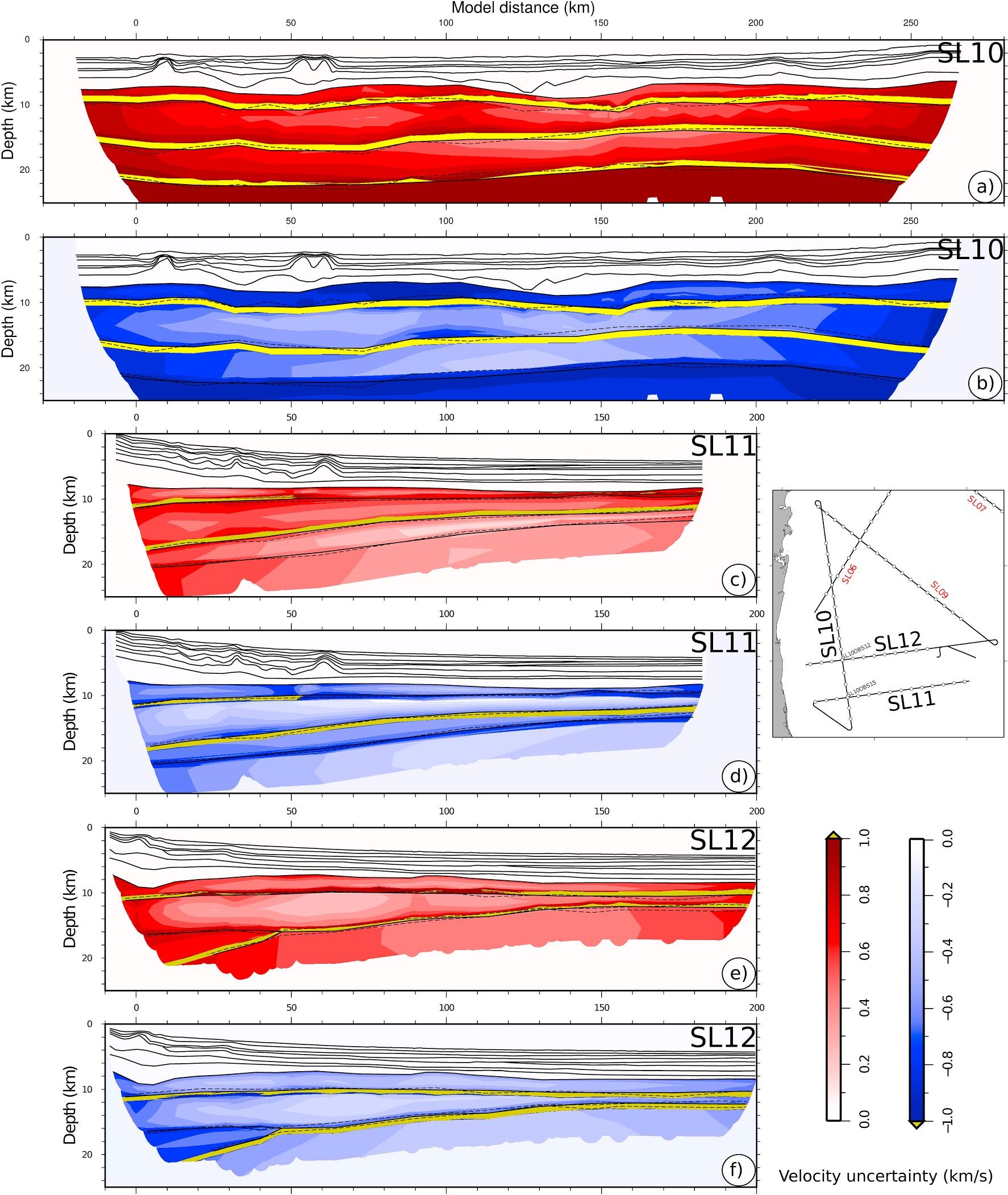


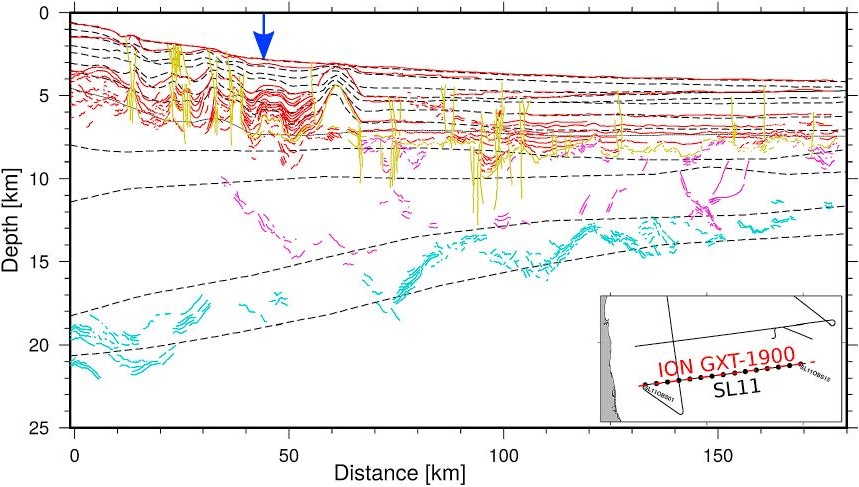




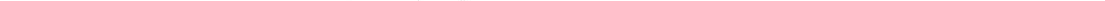




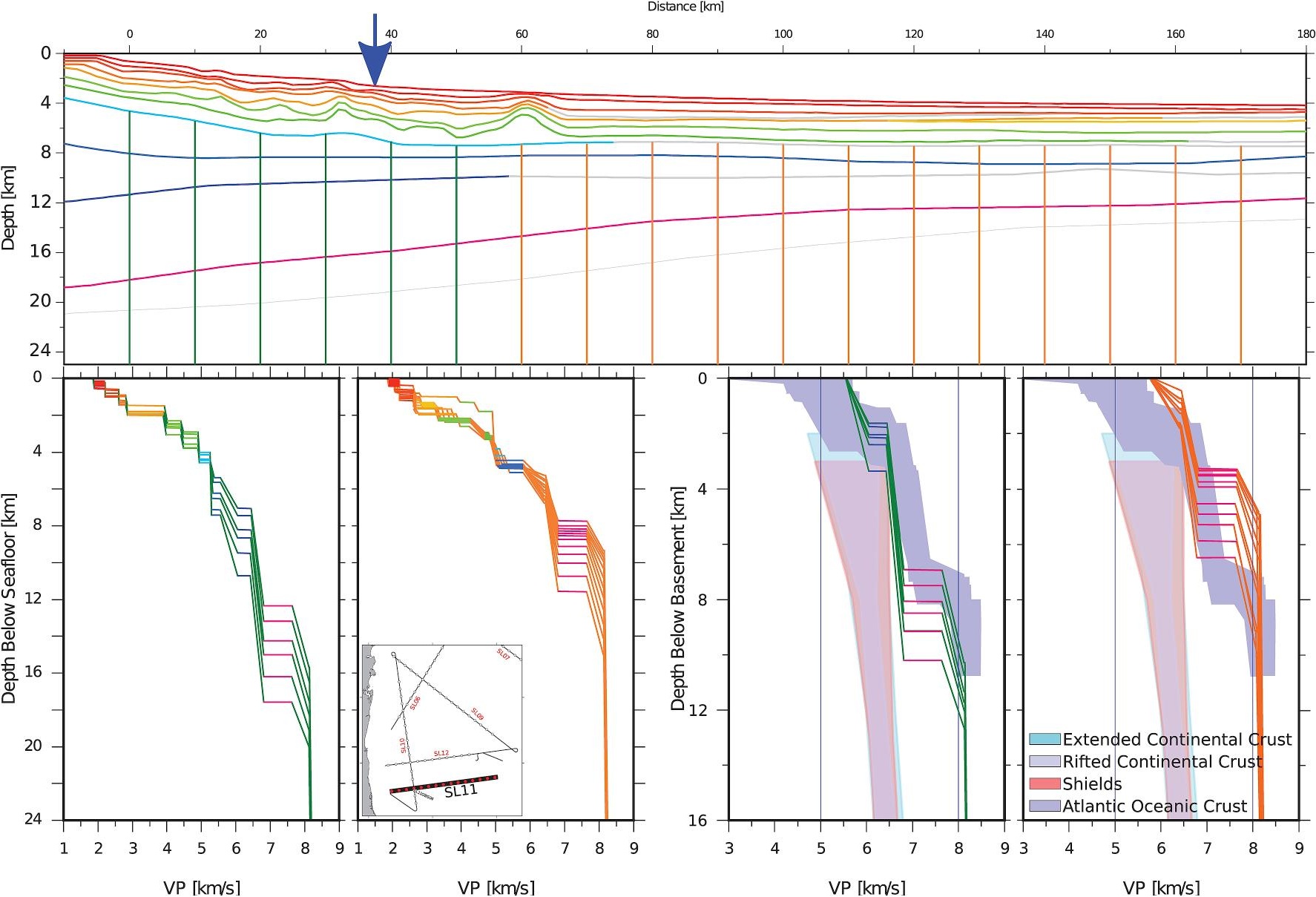




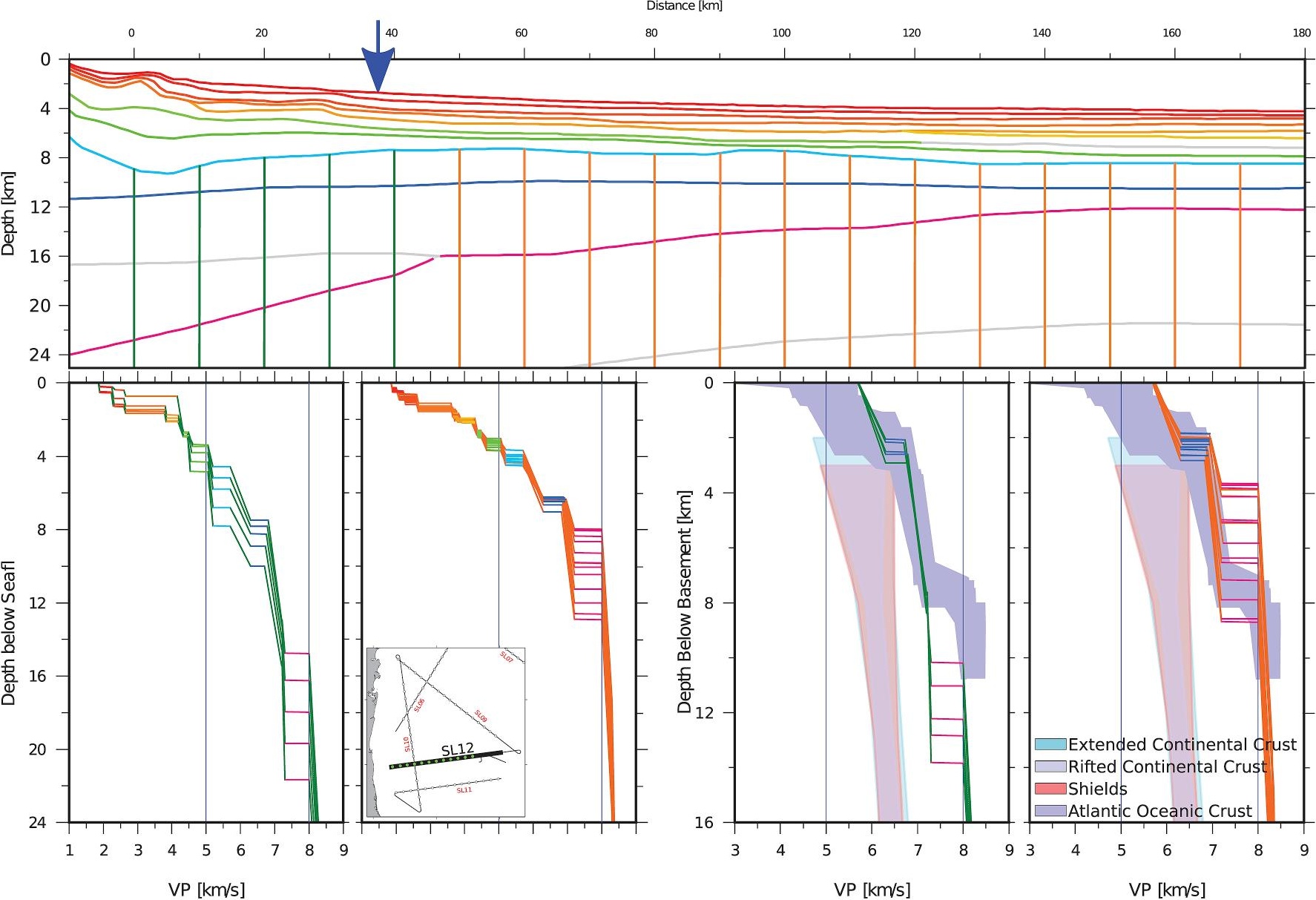




$$
\text { mYMBM }
$$


Exhuned / serpentinised Mantle
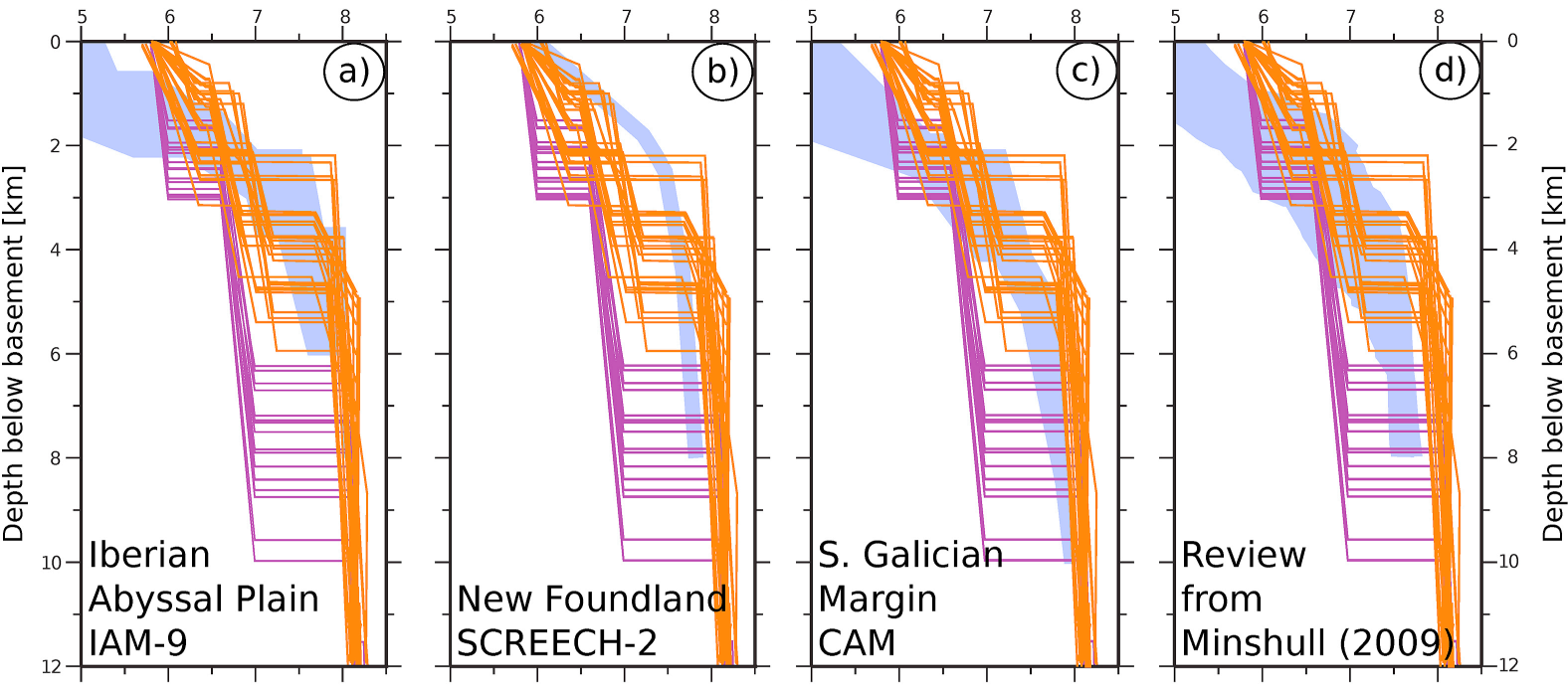

\section{Exhumed Cont. Crust}

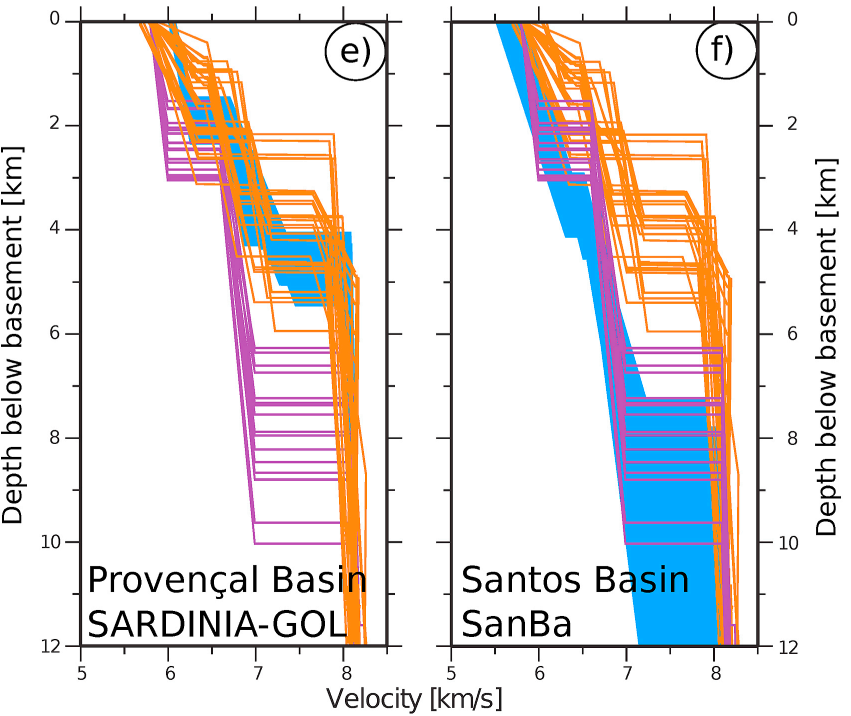




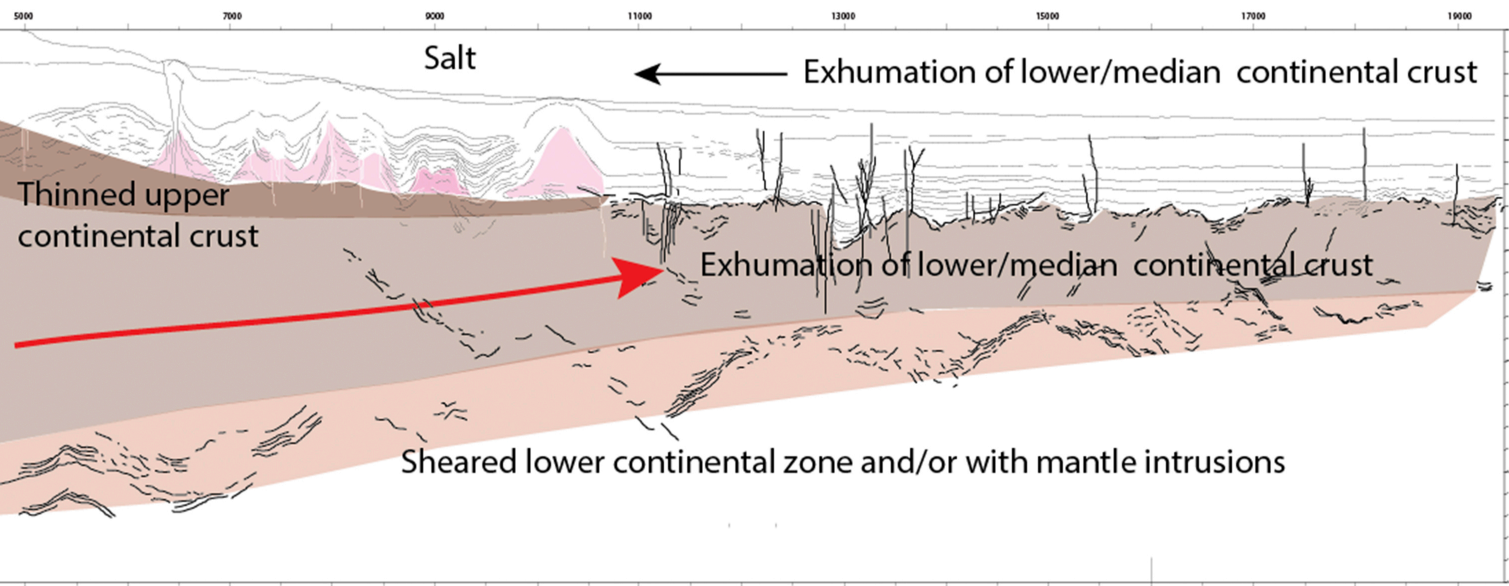

